DANILLO GIMENES VILLA

\title{
PAISAGENS PRÓXIMAS \\ O DESENHO E A DÚVIDA SOBRE ONDE AS COISAS ESTÃO
}

Tese apresentada ao Programa de Pós-Graduação em Artes Visuais, área de concentração Poéticas Visuais, linha de pesquisa Processos de Criação em Artes Visuais, da Escola de Comunicações e Artes da Universidade de São Paulo, como exigência parcial para obtenção do título de Doutor em Artes, sob a orientação do Prof. Dr. Marco Francesco Buti.

São Paulo

2012 
Autorizo a reprodução e divulgação total ou parcial deste trabalho, por qualquer meio convencional ou eletrônico, para fins de estudo e pesquisa desde que citada a fonte.

\section{Catalogação na publicação \\ Serviço de Biblioteca e Documentação \\ Escola de Comunicações e Artes da Universidade de São Paulo}

Villa, Danillo Gimenes

Paisagens próximas, o desenho e a dúvida sobre onde as coisas estão. / Danillo Gimenes Villa. - - São Paulo : D. G. Villa, 2012.

298 p. : il.

Tese (Doutorado) - Escola de Comunicações e Artes/ Universidade de São Paulo.

Orientador: Prof. Marco Francesco Buti

1. Desenho 2. Paisagem 3. Espaço (Arte) I. Buti, Marco Francesco II. Título.

CDD 21.ed. -741 
BANCA EXAMINADORA

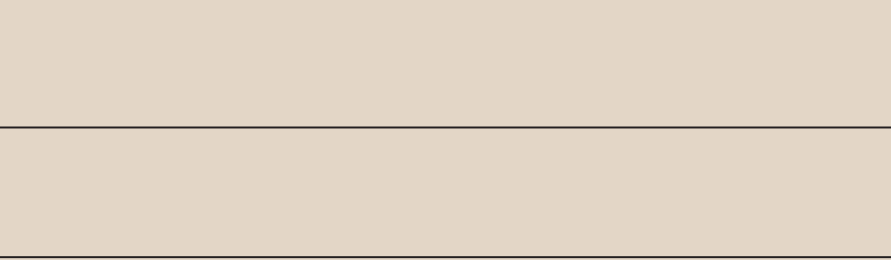



Para minha mãe e meu pai 



\section{AGRADECIMENTOS}

D. Amanda Totti, minha primeira professora de arte, que me ajudou, com seu respeito pelo menino que eu fui, a me tornar o professor que eu sou. Elke e Nina, por me ajudarem, sempre e sem restrições, em meus movimentos para fora. Me libertaram. Marika, pela impaciência. Buti, que conhece as paisagens iniciais e desde lá me orienta. Tânia, por ter me perguntado em momentos muito importantes se eu estava bem. Henrique e Felipe, por serem pequenos. Minha avó Bina, por ser grande. Minha avó Helia, por enfeitar minha infância. Cidade de Echaporã, onde tudo é paisagem.

Cidade de Londrina, por ser guardiã de alguns dos meus segredos. José Sanches, por viver na minha memória me perguntando: em que você anda interessado?

Cinthia, pela maior ataque de riso que tive na vida, as palavras inventadas, os palavrões, as discussões interessadas

e o coração - 7389.

Aos meus alunos da Universidade Estadual de Londrina, por me mostrarem renovações possíveis todos os dias. 

O presente trabalho se constitui de um conjunto de desenhos realizados nas ruas de Londrina - PR, e São Paulo - SP, entre os anos de 2009 e 2011. Esquinas, partes da cidade, placas de sinalização e carros velhos arriscam uma localização. Entretanto, a aproximação de referências ligadas a uma linhagem de entendimento do espaço que parte de Cézanne e aproxima Morandi, De Chirico, Brancusi e Mestre Vitalino entre outros, acaba por testar e ampliar a conceituação da paisagem, justamente, entendo, através daquilo que é próximo e que mesmo assim, talvez por isso mesmo, torna os espaços representados mais e mais complexos.

Palavras-chave: desenho, paisagem, espaço. 

This project refers to several drawings which were made from 2009 to 2011 on the streets of Londrina and São Paulo. Parts of town such as corners, signs and old cars take a risk at finding the perfect site. The reference proximity connected to a space situated language understanding, which goes from Cézane and reaches Morandi, from Chirico, Brancusi and Mestre VItalino among others, tests the landscape concept and widen it. Therefore I can understand that through what is near the represented spaces - and perhaps because of it - become more and more complexes.

Key-words:drawing, landscape, space. 



\section{3}

6 DE CHIRICO

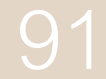

\section{VOLPI E GOELDI}

\section{8}

LE DÉJEUNER SUR L'HERBE

9 MATERIAIS, UM QUASE

10 OS OBJETOS

11 PAISAGENS

12

CORES INICIAIS

13 DO QUE AINDA

14 SOBRE A BIBLIOGRAFIA

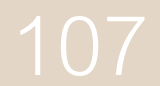

113

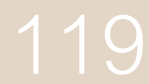

125

103

231

270

207 

Desenho paisagens observando seu surgimento. 

SOBRE ONDE AS COISAS ESTÃO 



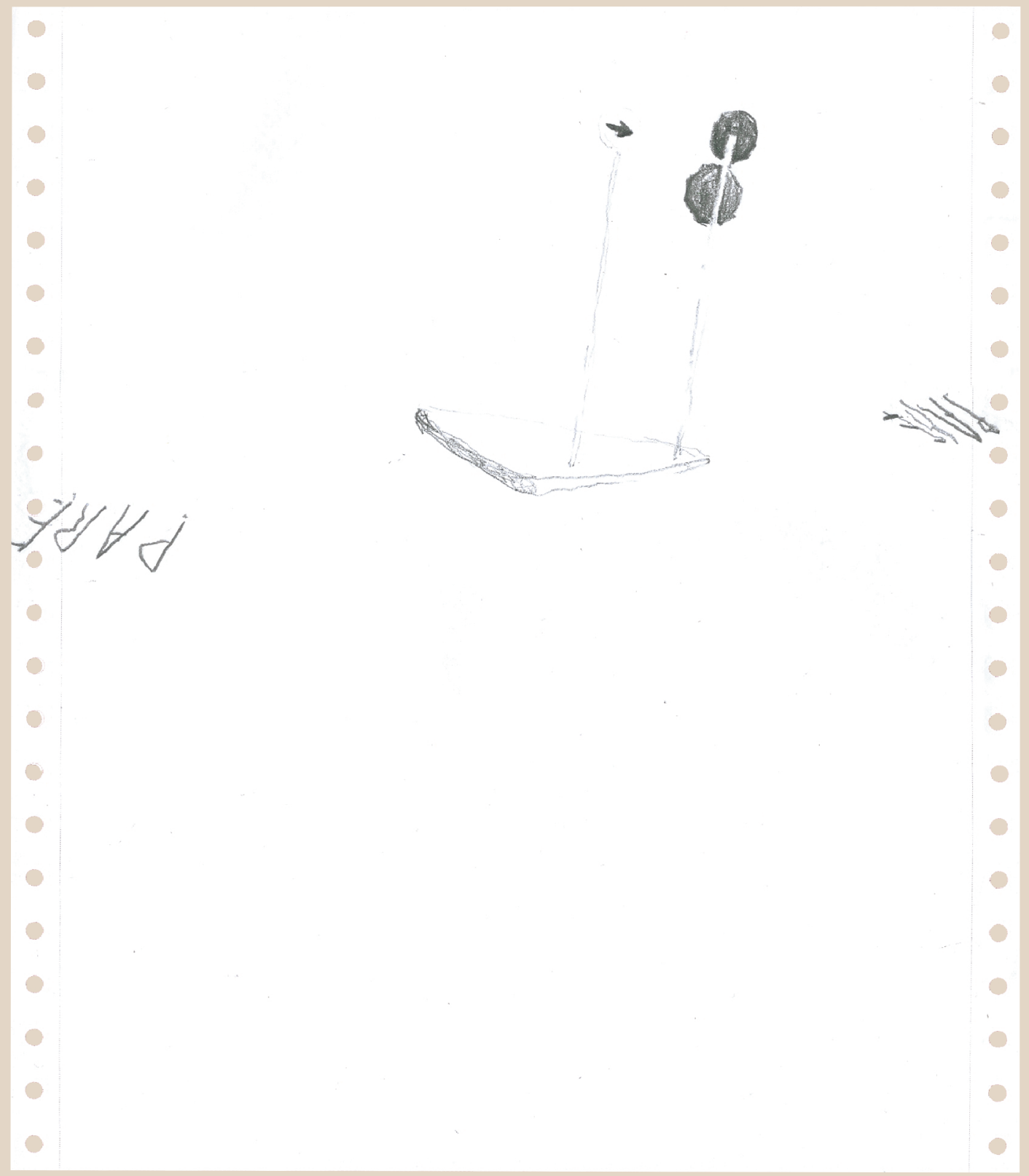





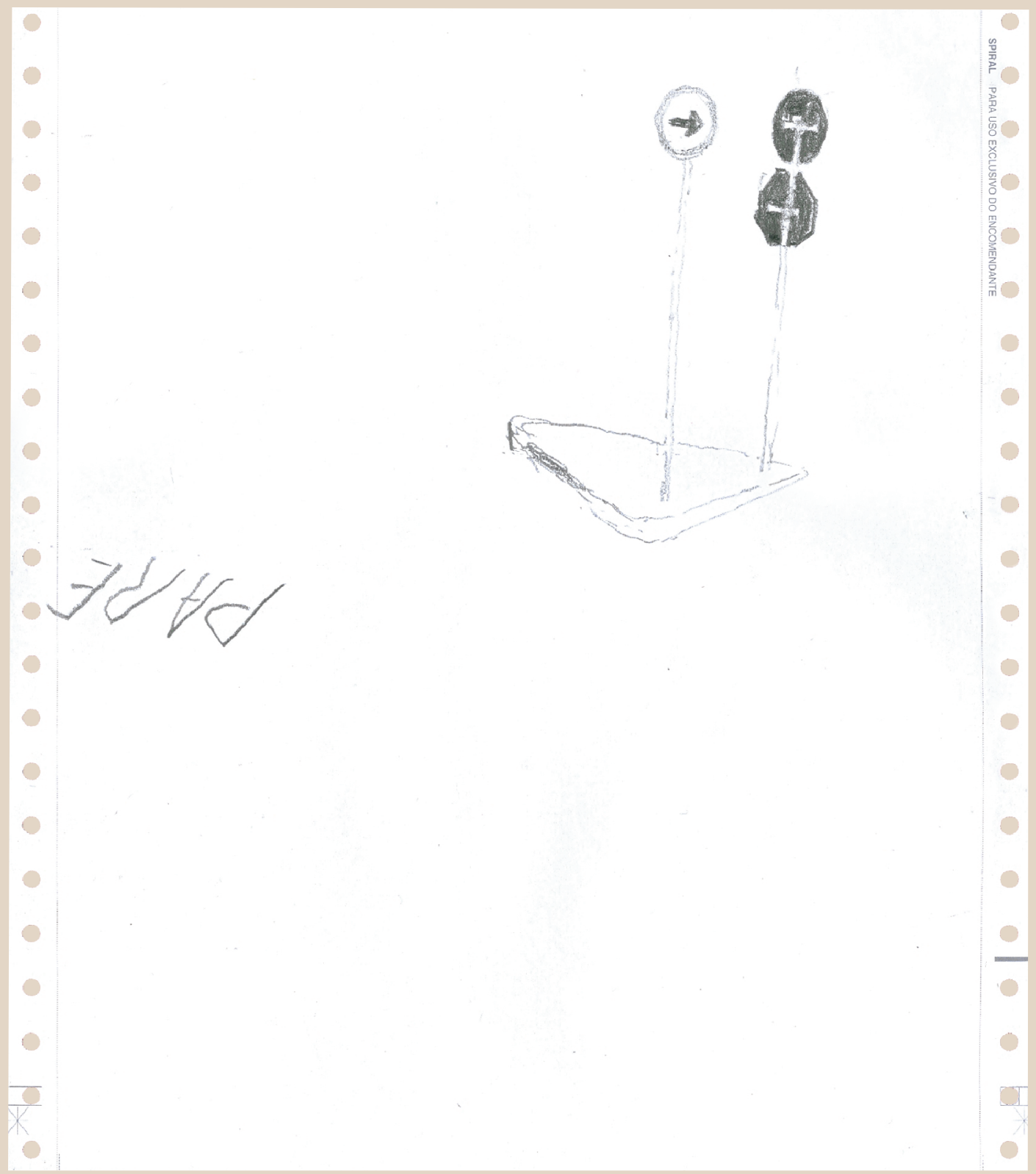




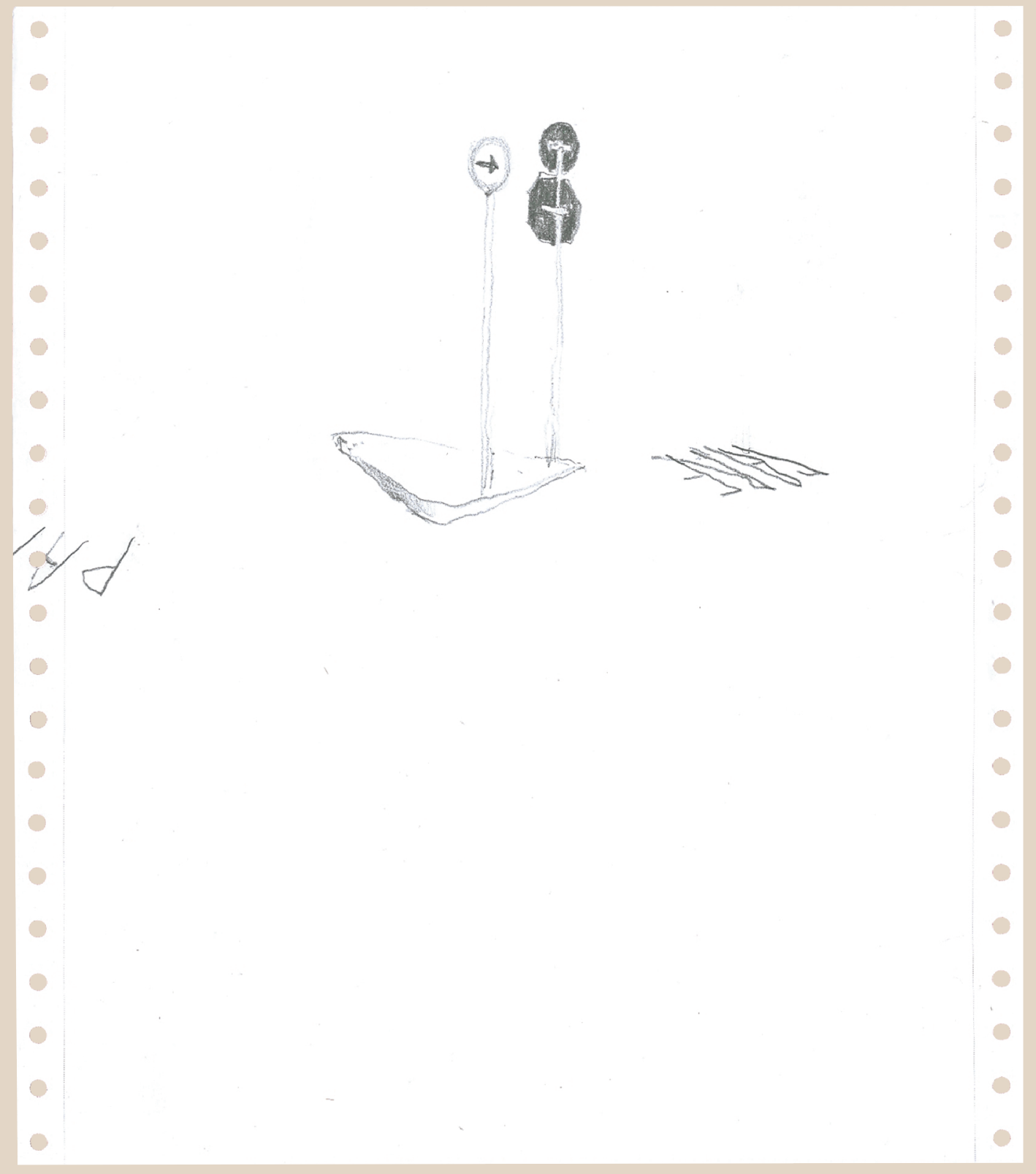




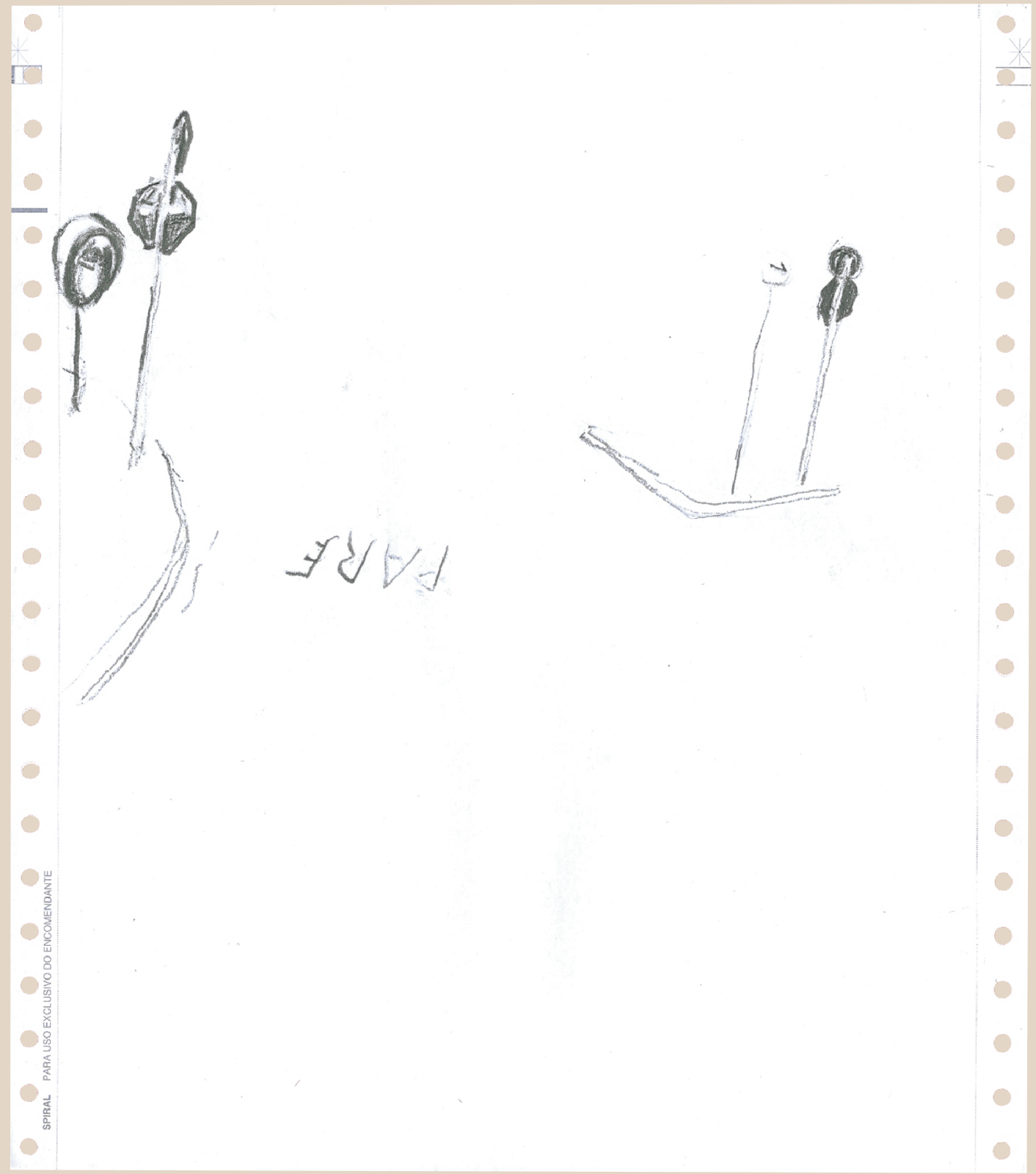


Os objetos que me atraem são poucos: uns carros com a cor envelhecida, umas placas de sinalização, uns pedacinhos de cidade - sua presença funciona como uma pequena caixa surpresa a ser aberta. Mas se os objetos se repetem, qual é a surpresa? Não há. Tudo permanece no mesmo lugar, a imagem não se atualiza, o tratamento não se atualiza, a coisa vista é um limite intransponível. O objeto tem uma presença determinante e reguladora e orienta o que vai acontecer no desenho. Não há fantasmas, não há mistérios insolúveis, só uma pequena porção vazia de cidade, que em traços delicados e econômicos, um vocabulário rudimentar, resulta em um desenho que parou na infância.

Assimilei a lição primeira dos impressionistas, ir para fora, ao pé da letra. Quando estou desenhando, na rua, me entrego àquilo que vejo, é o que me interessa, qualquer movimento altera o trabalho, pretendo ser invisivel, desaparecer na paisagem, silenciarme.

Queria que desenhar e depois, o resultado, me tornassem mais misterioso, eu desapareceria nas coisas que vejo e assim nas pequenas perspectivas desenvolvidas nos desenhos, nestes arranjos de poucos objetos, haveria um estado de presença, uma familiaridade que me permitiria ser em silêncio.

As pessoas arriscam dizer que meu desenho parece infantil e realmente me perco naquilo que vejo como uma criança em formação, tateando e experimentando tudo com todos os sentidos abertos. O desenho se faz com fricção, me deixando imantado aos objetos que escolho. 


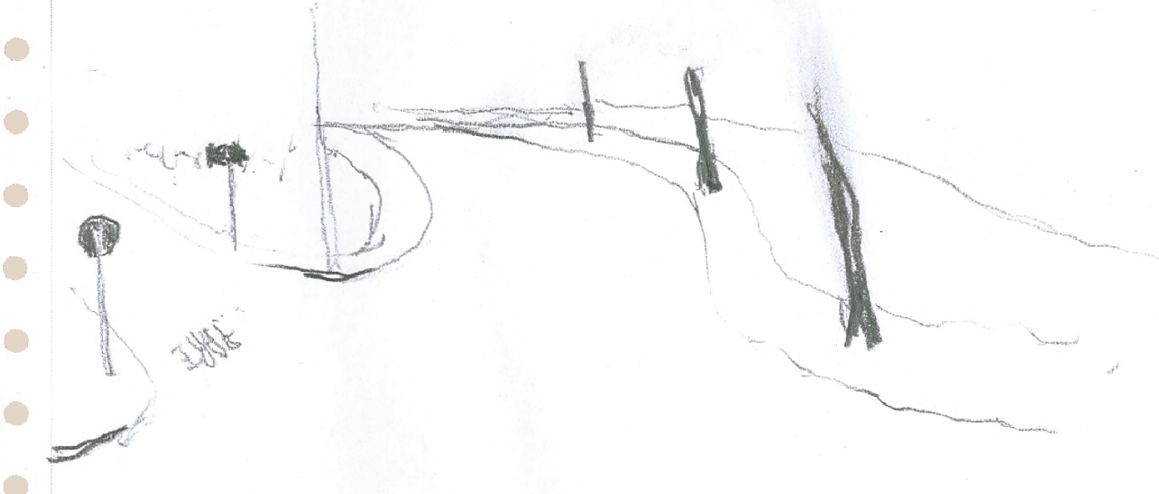




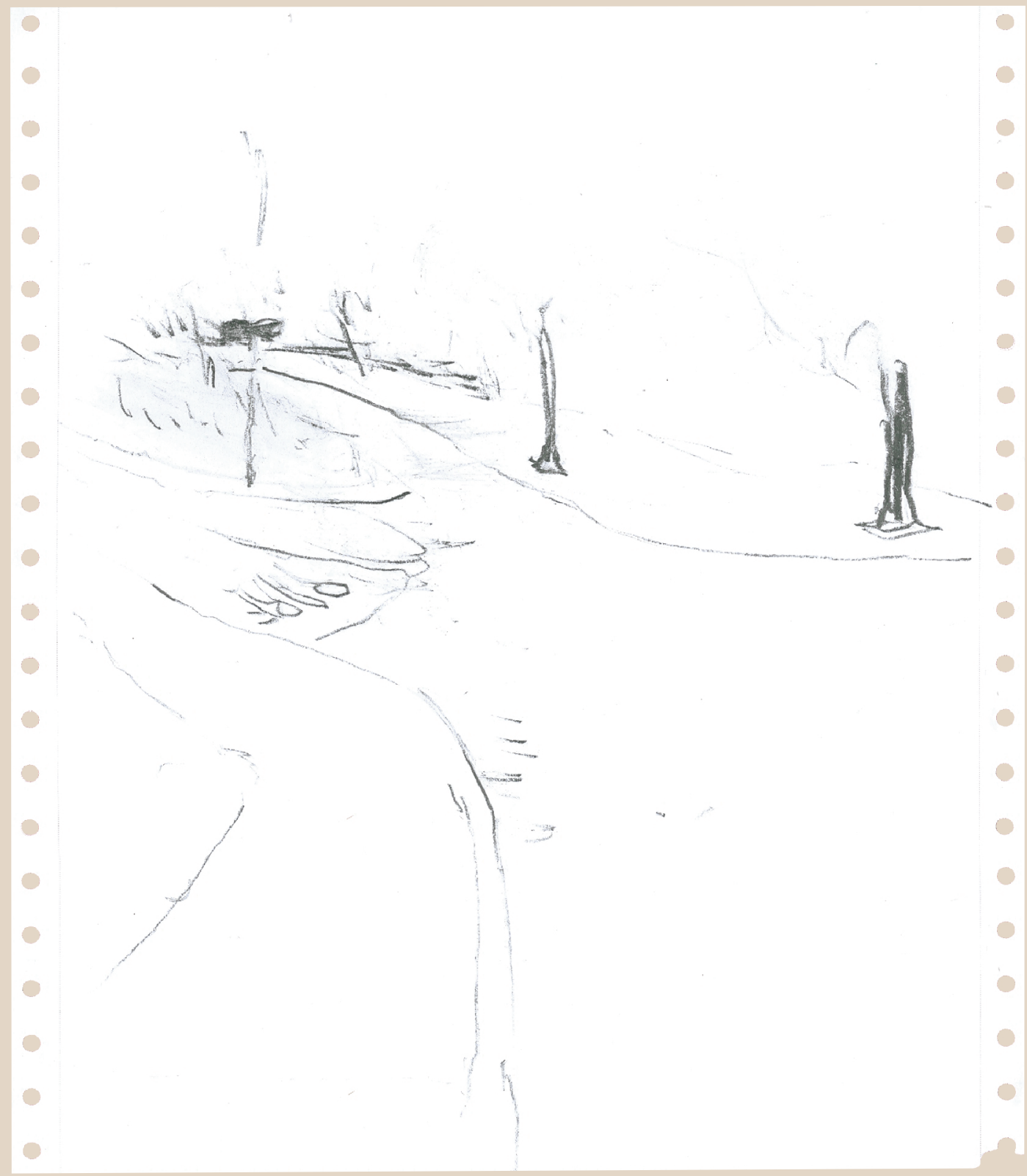




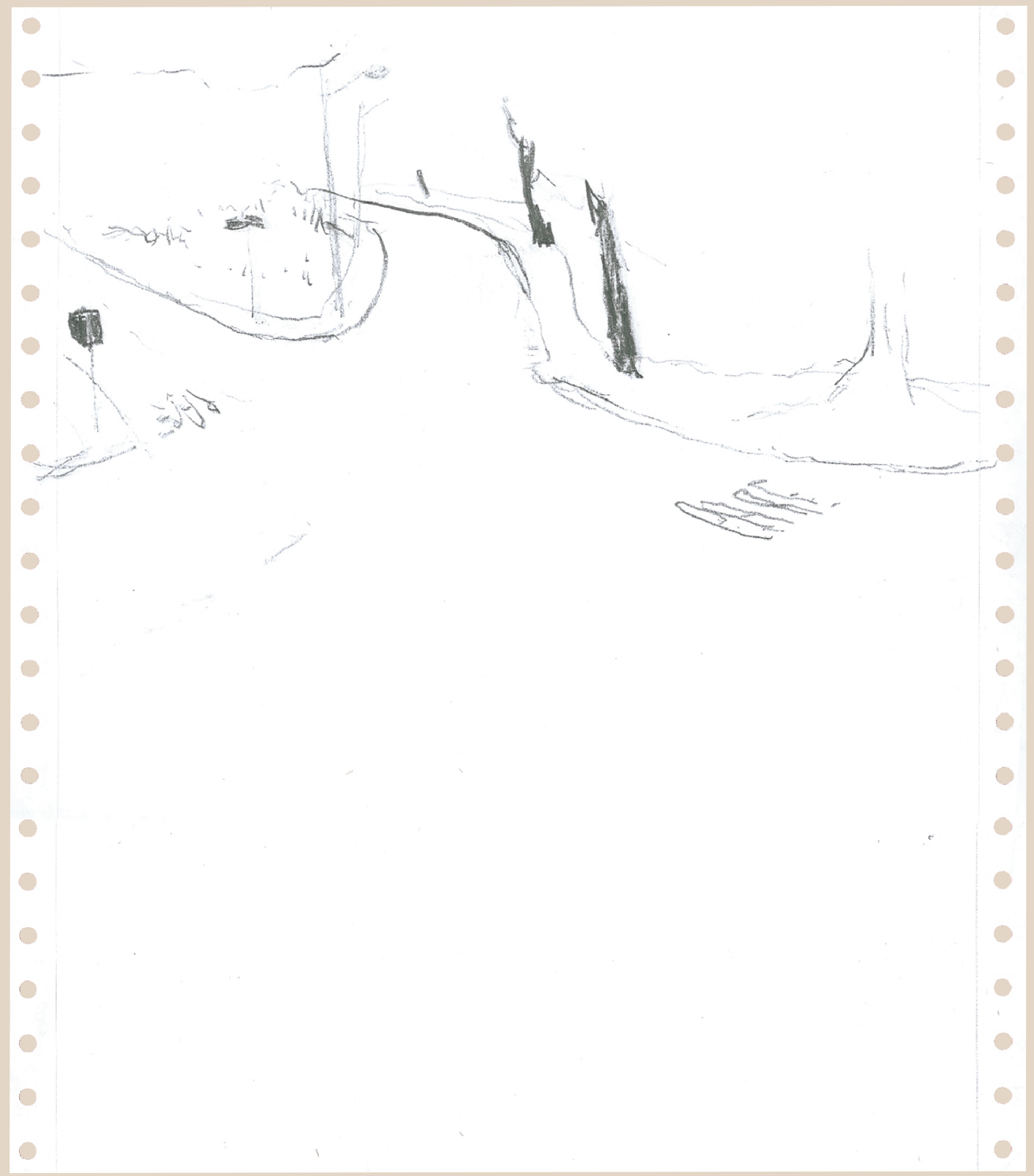




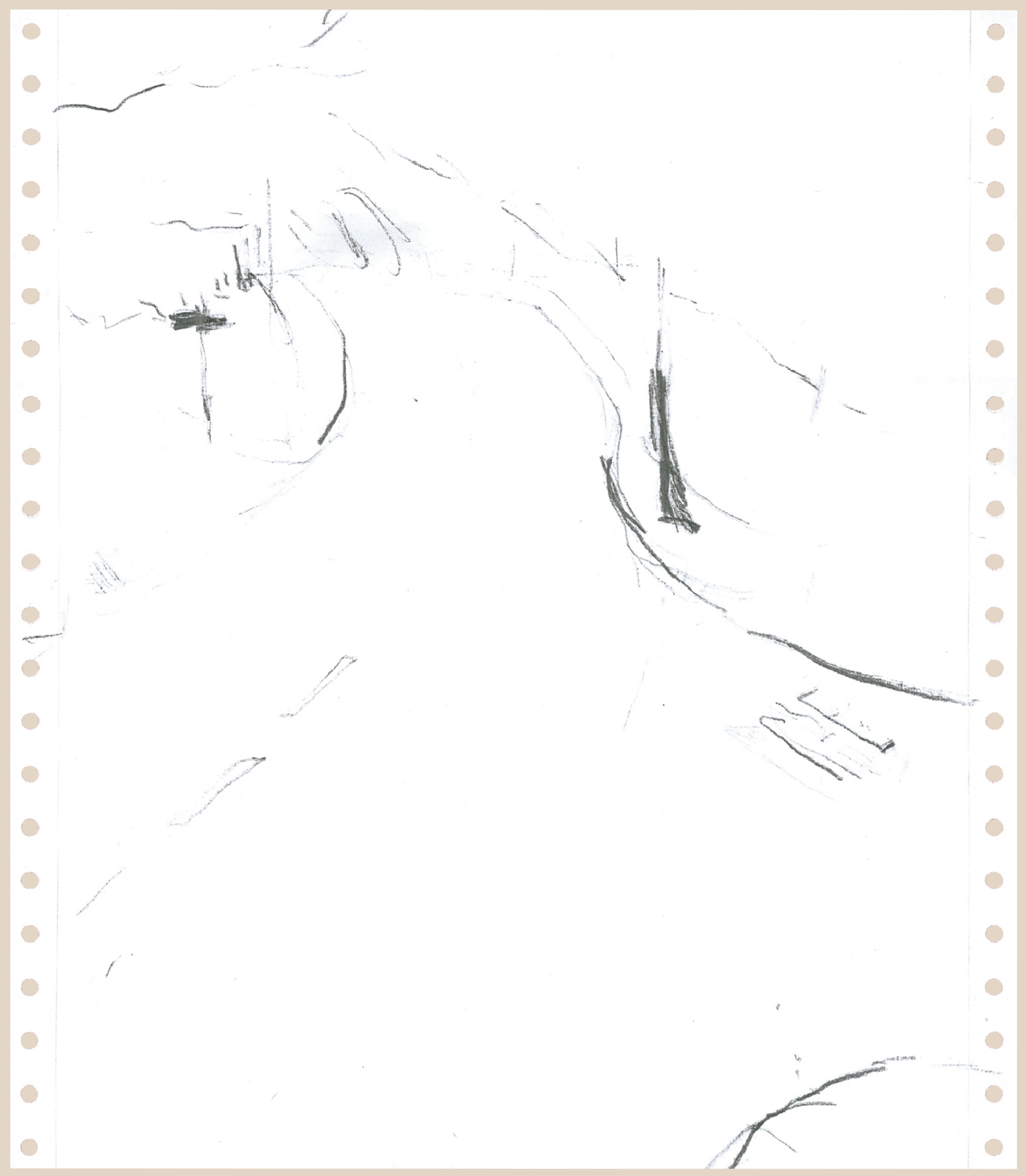




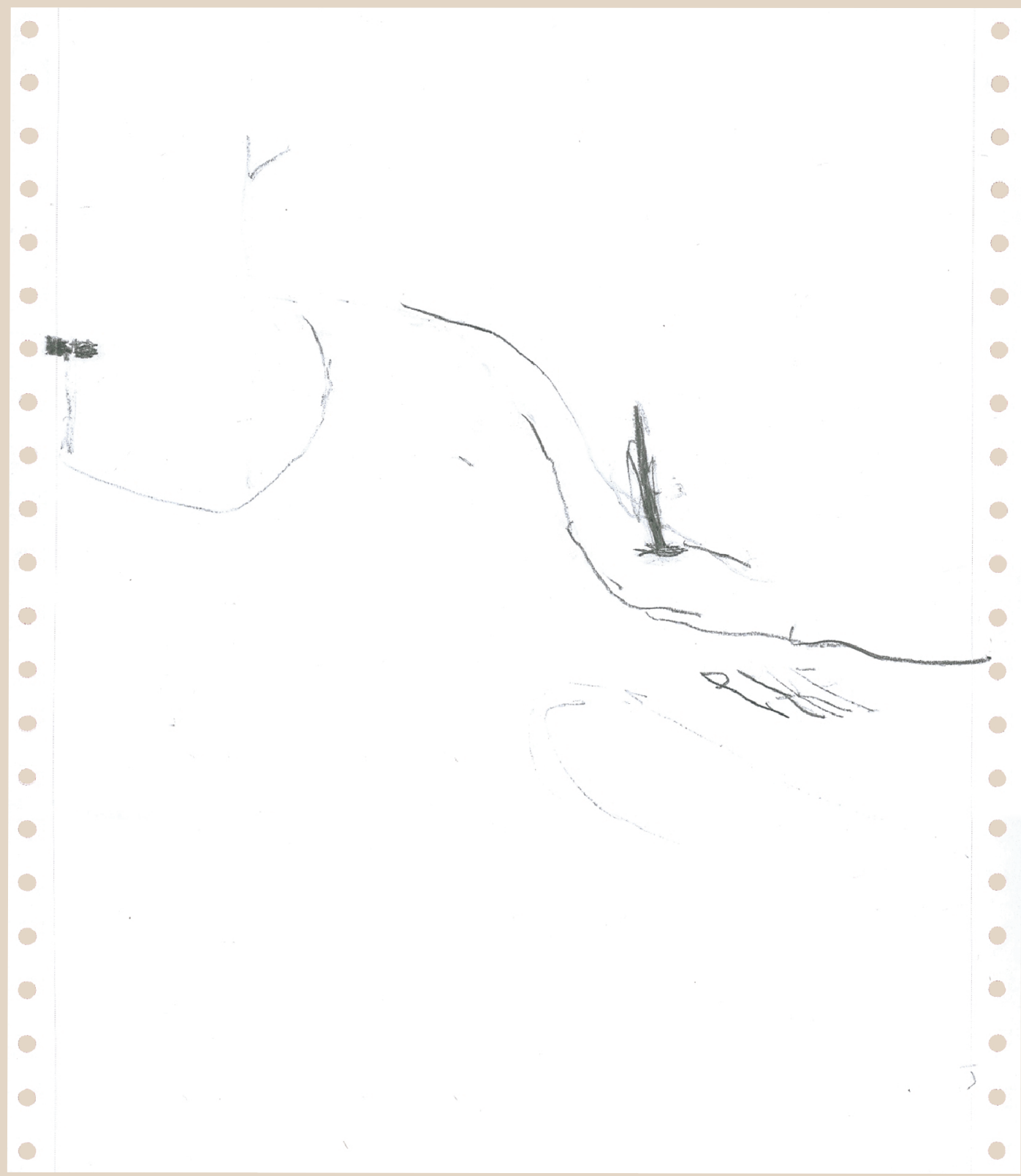




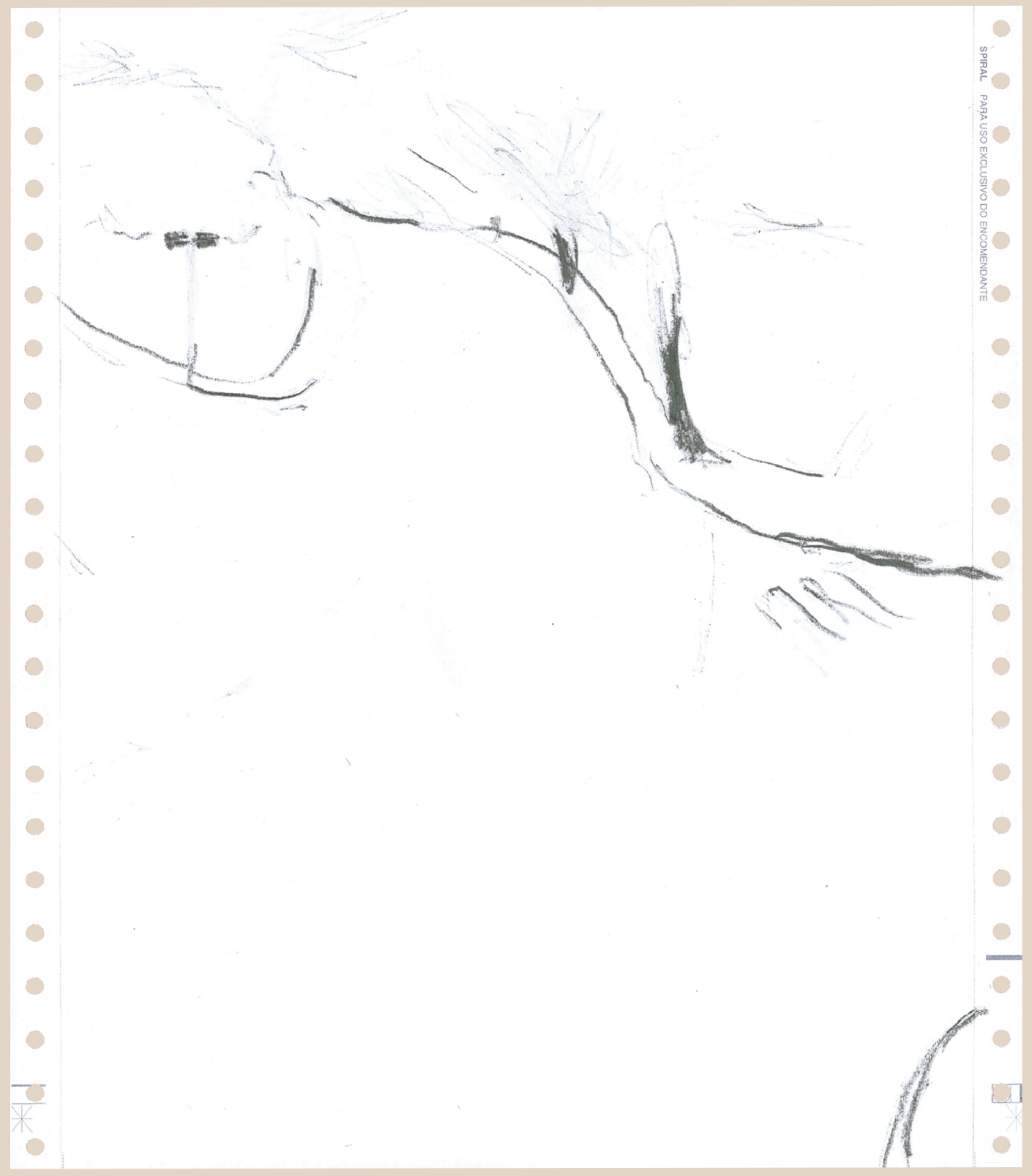


Os desenhos são articulados de maneira enviesada, o ponto para onde estou olhando não é aquele que estou desenhando. Este pequeno descompasso me faz perceber, no processo, algo vivo e autônomo que se manifesta enquanto desenho. Persigo esta energia, não olhando diretamente, mas desenhando pelas bordas, favorecendo um fluxo paralelo de sensações. 


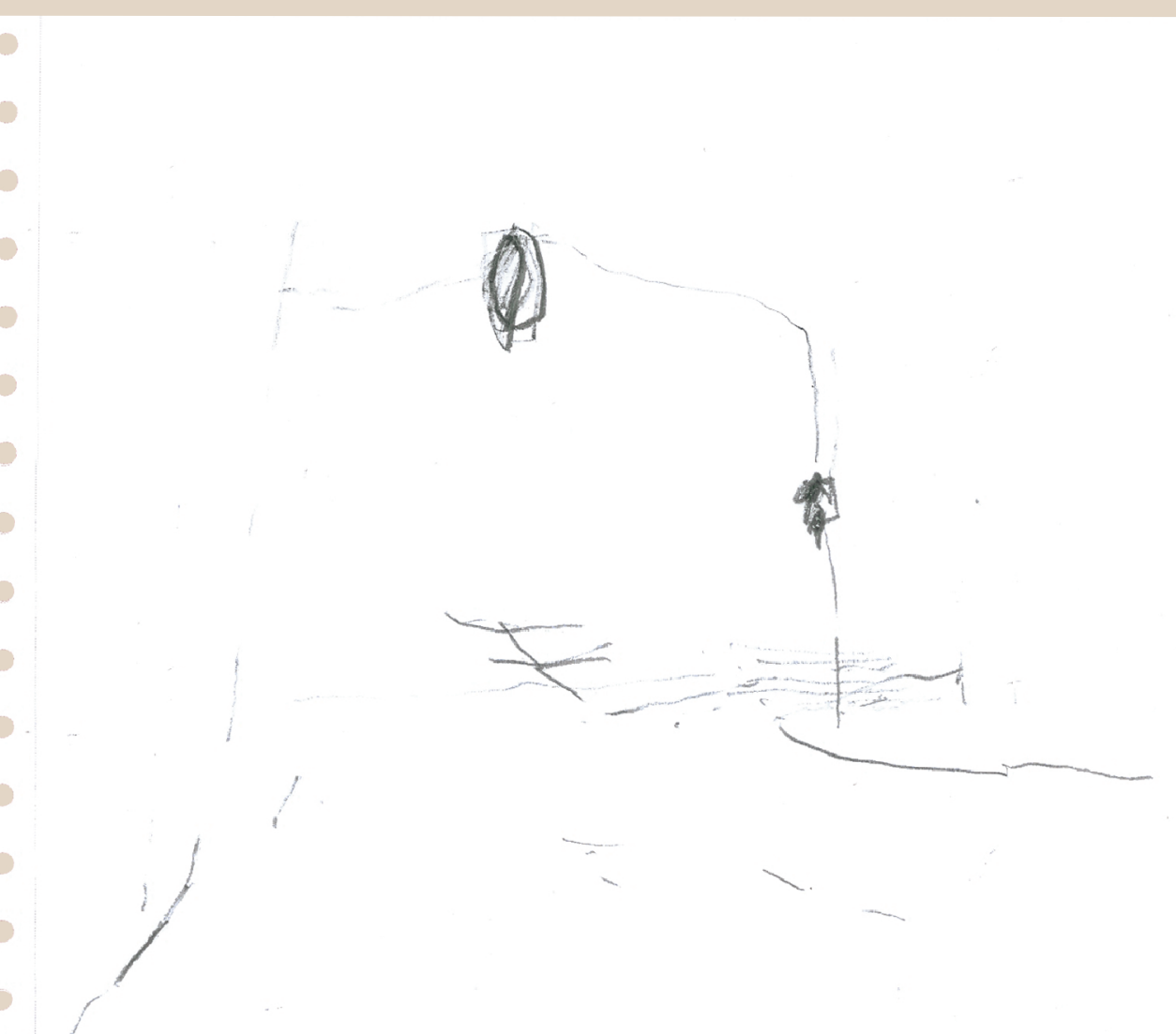




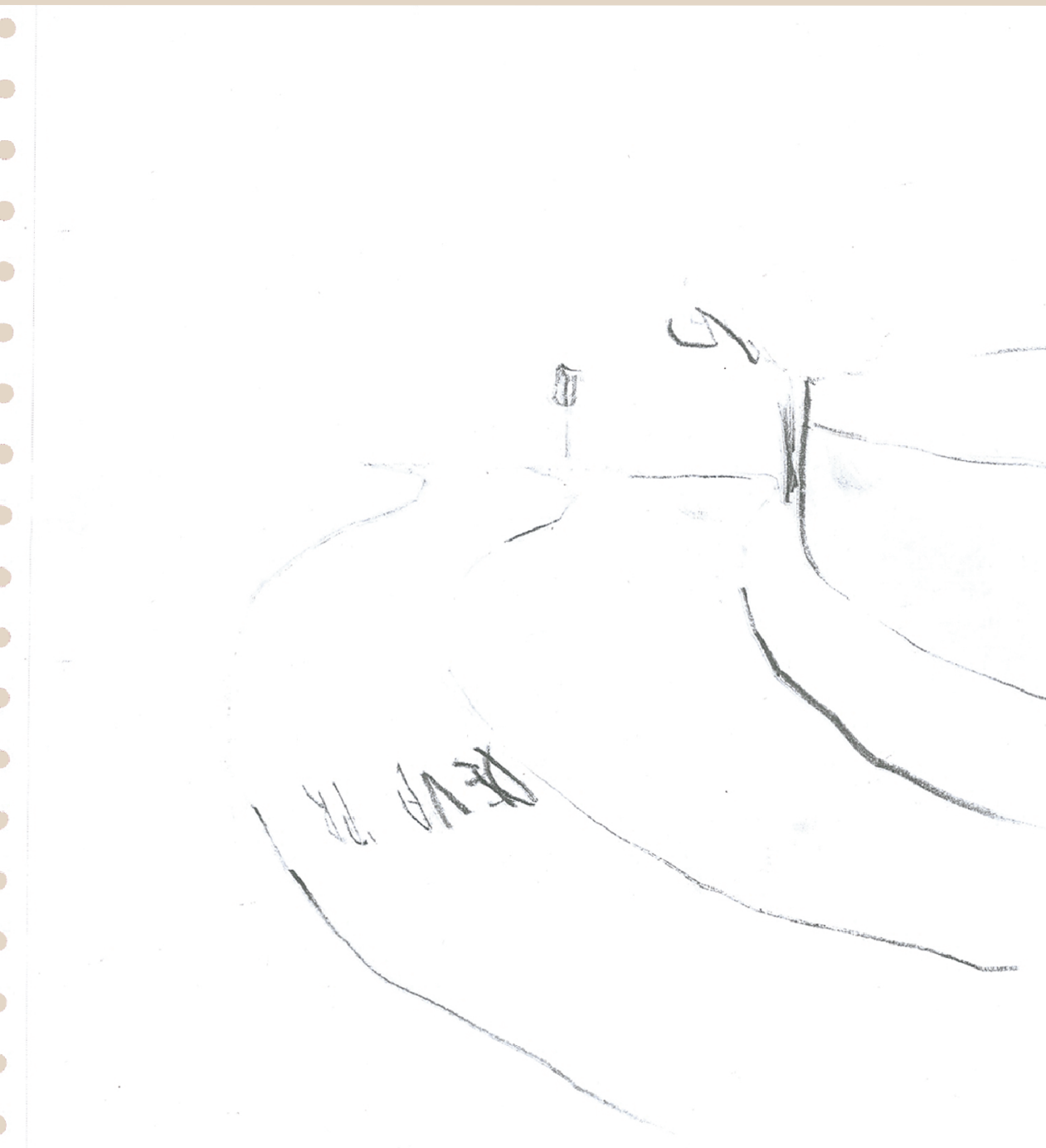




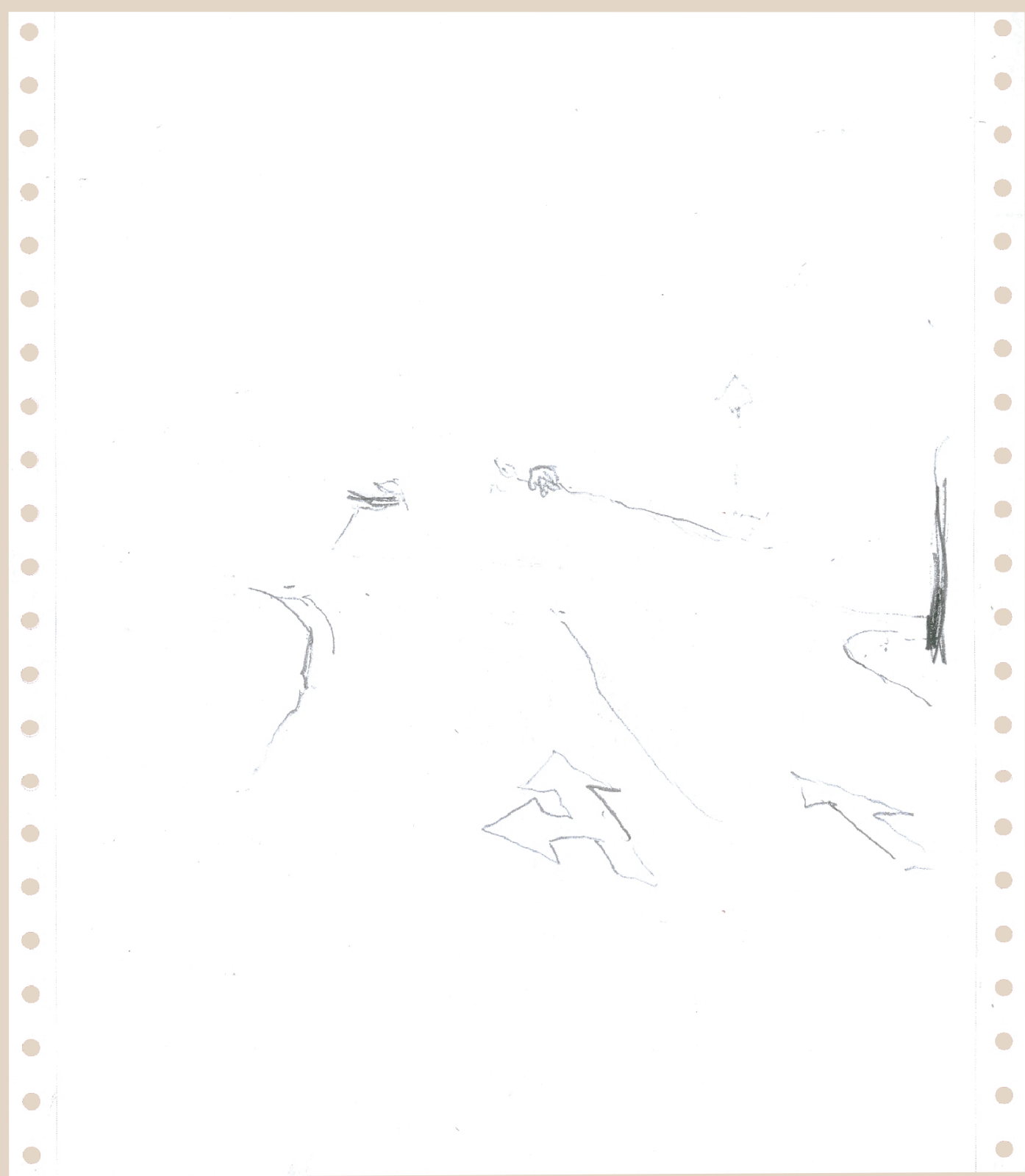




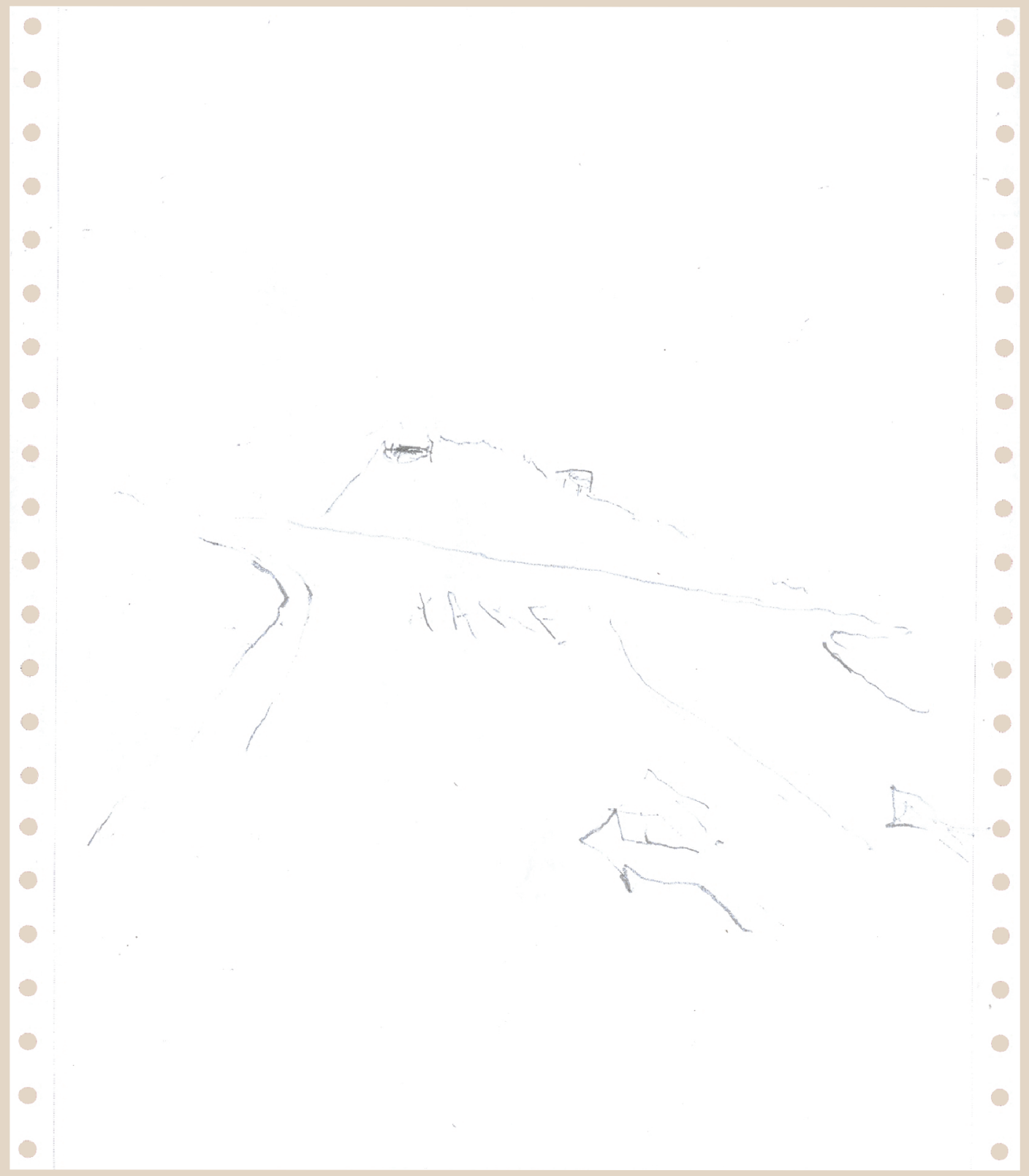




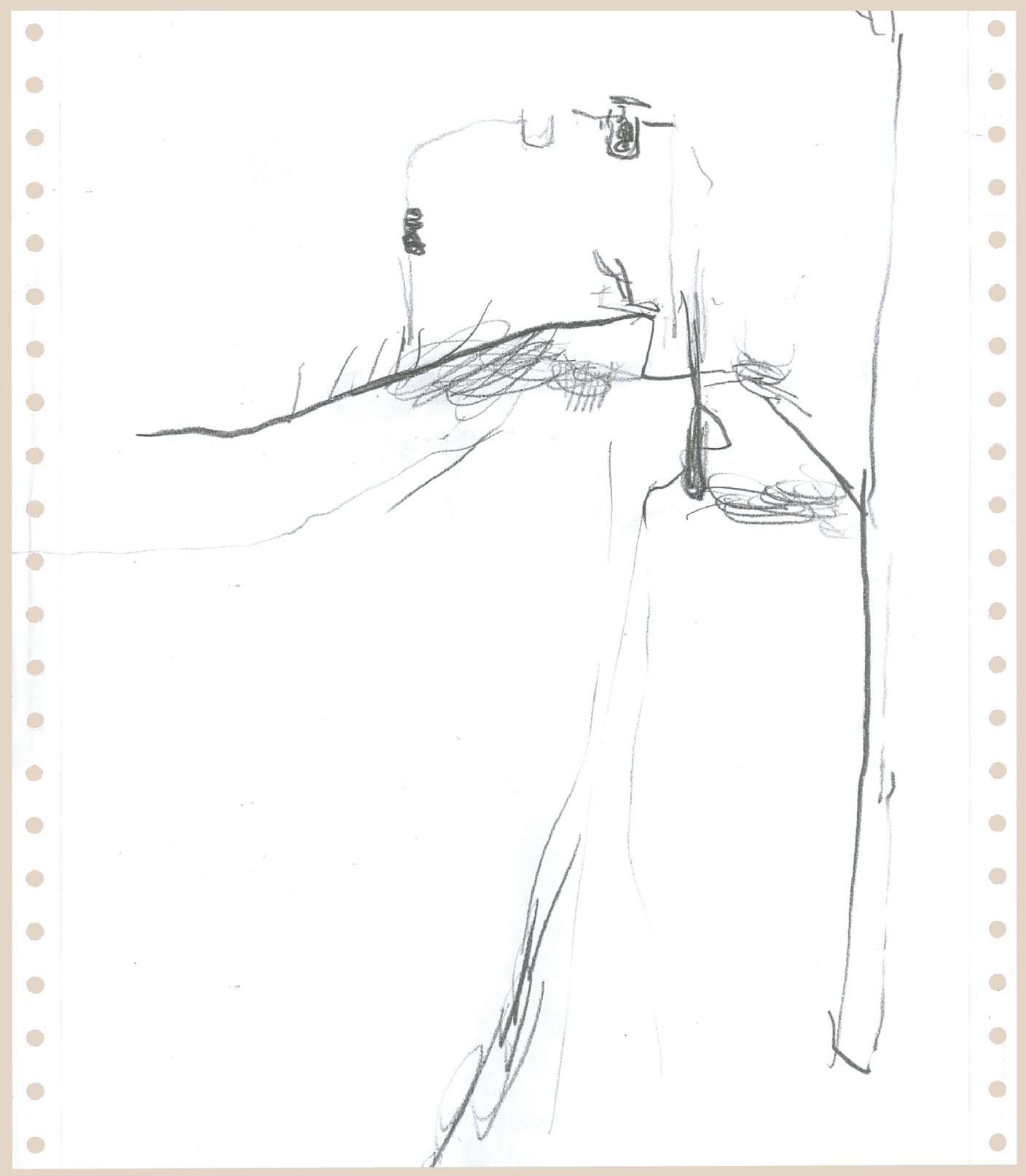




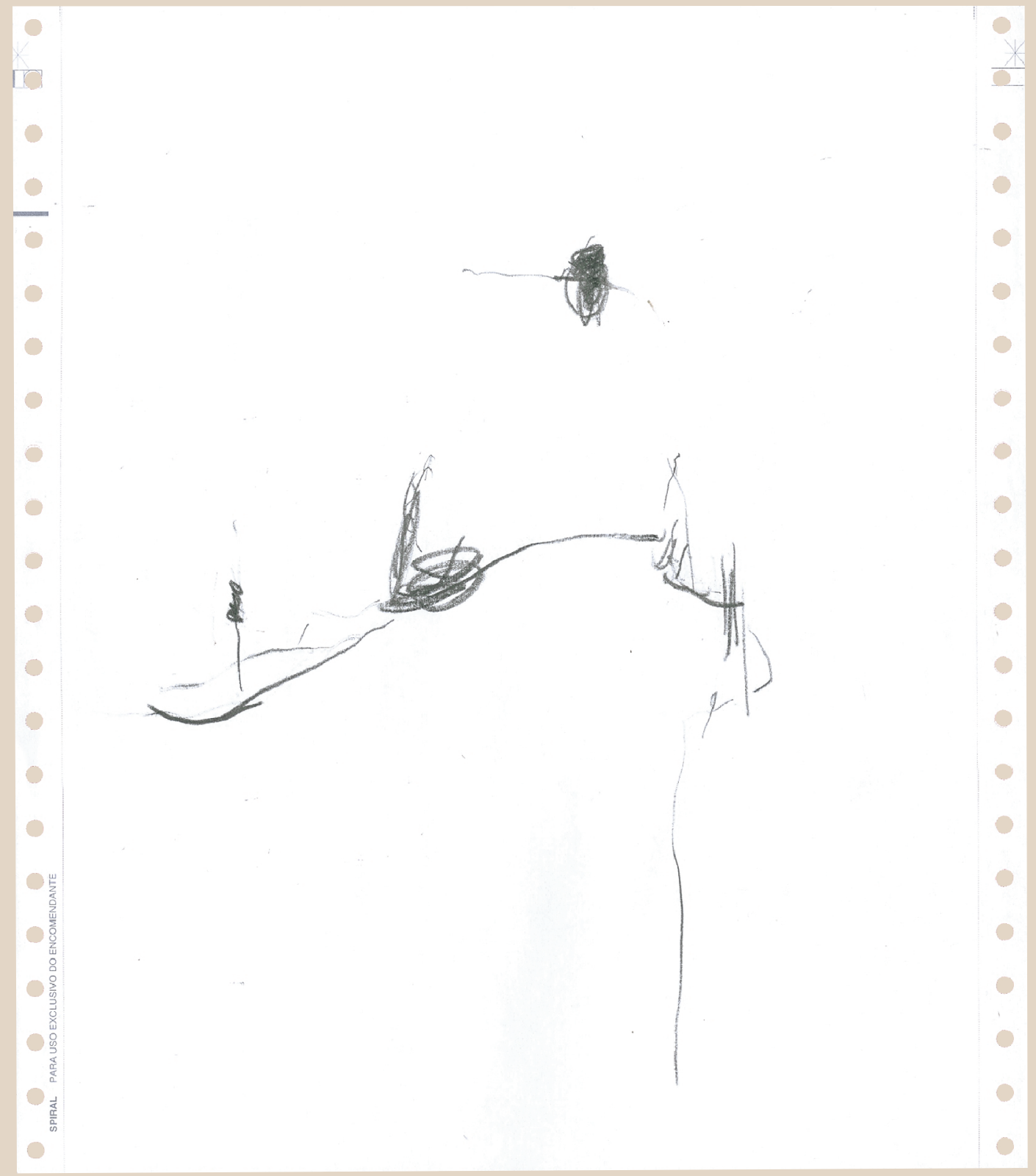




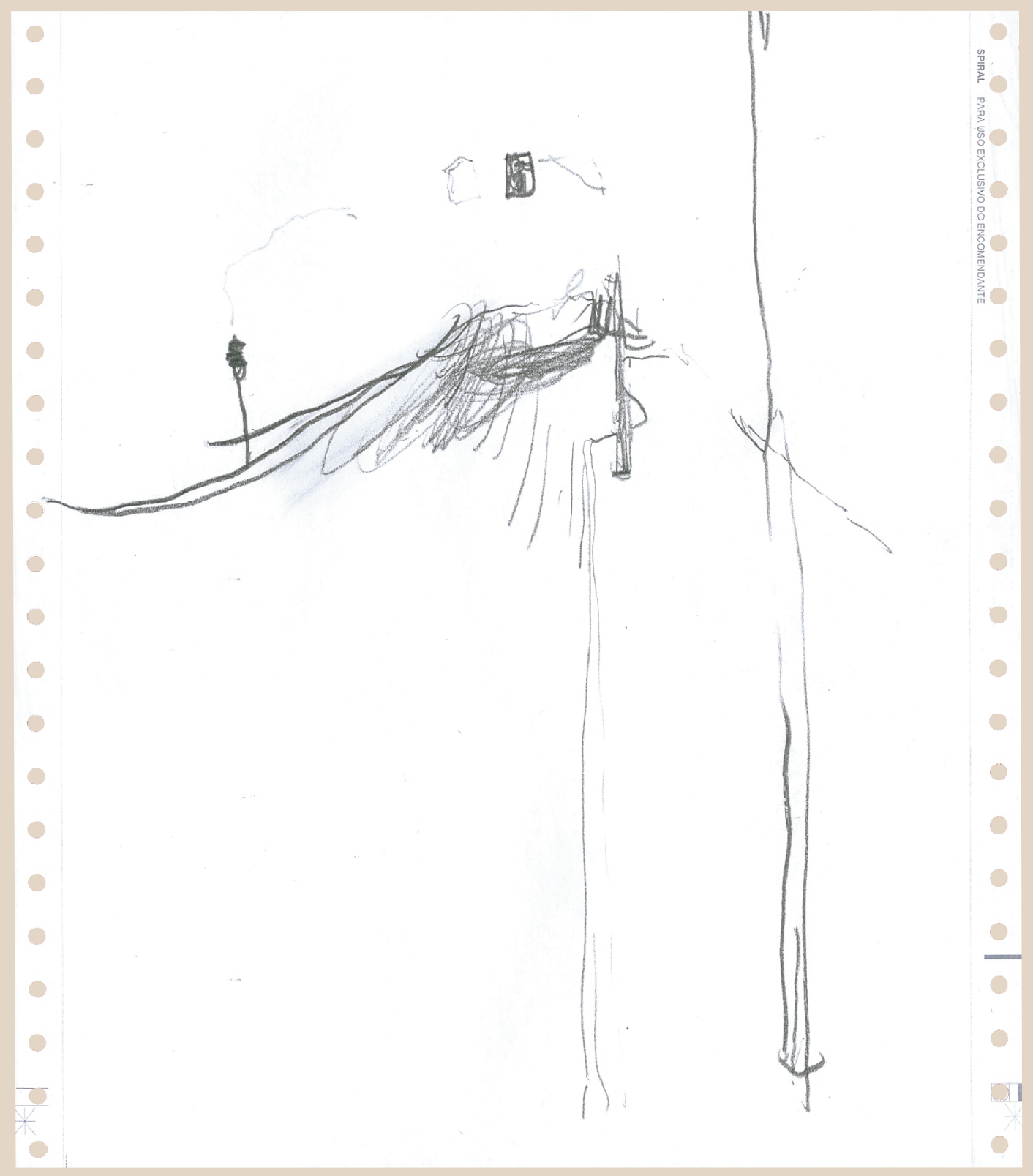




$$
\text { is }
$$




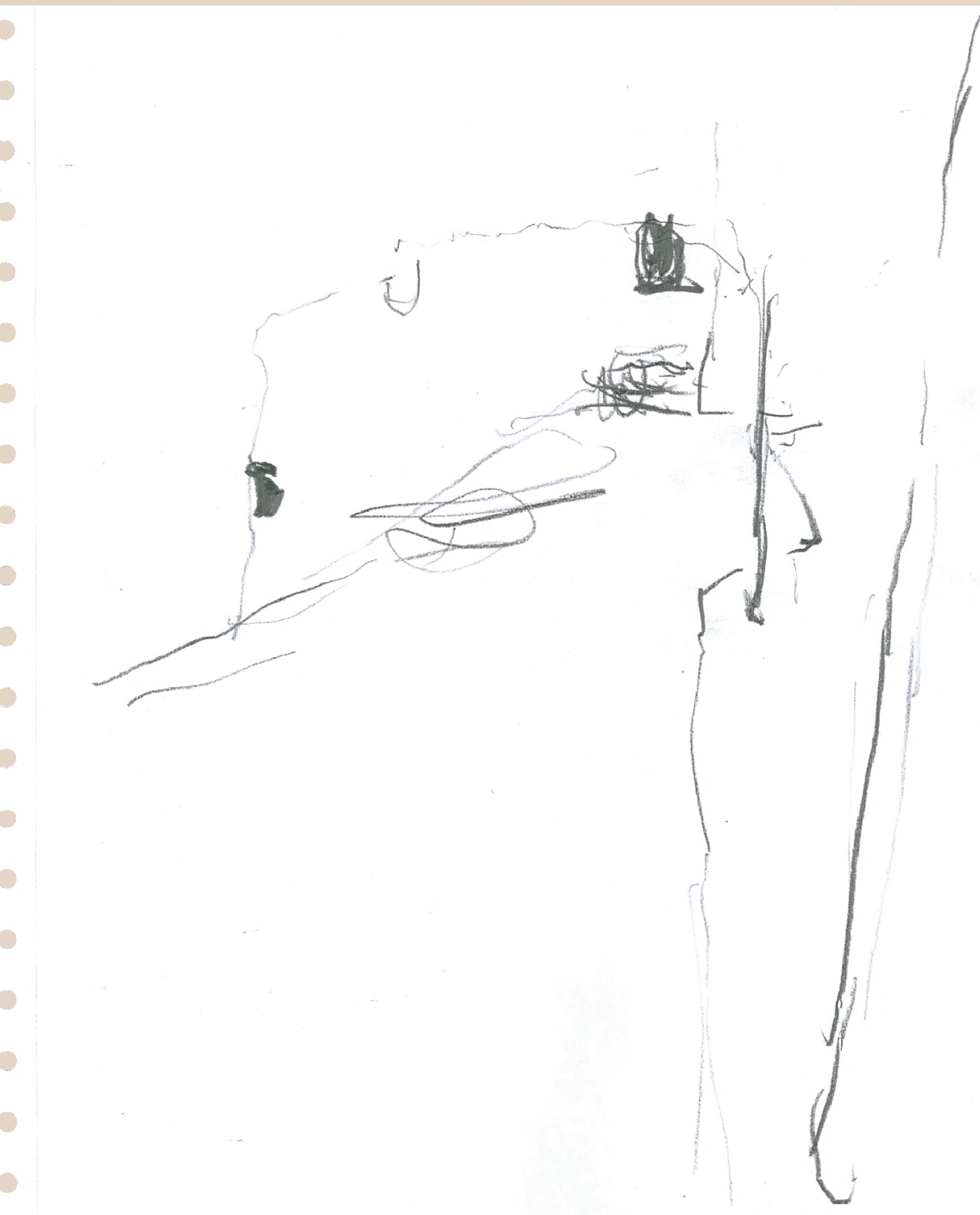




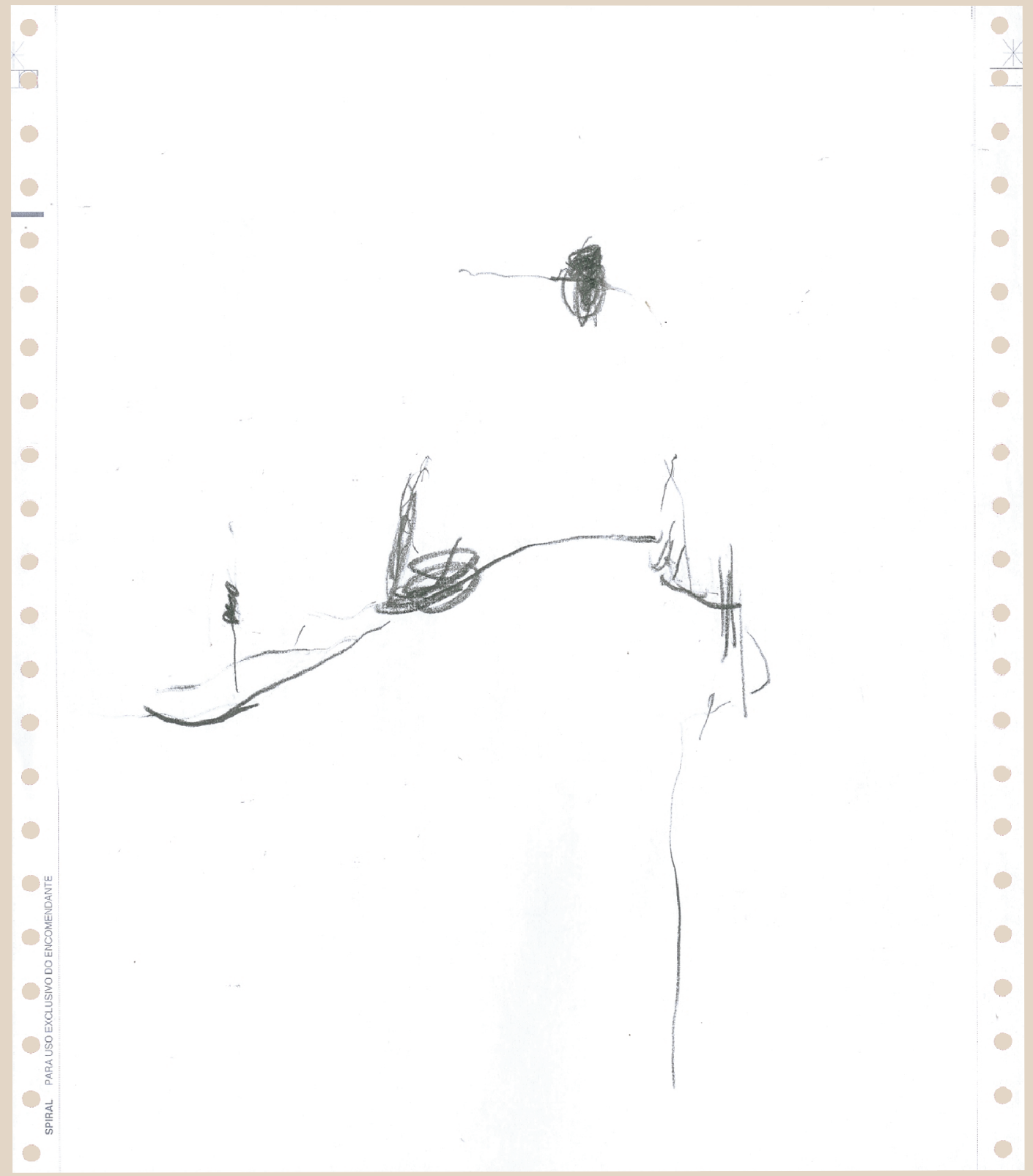




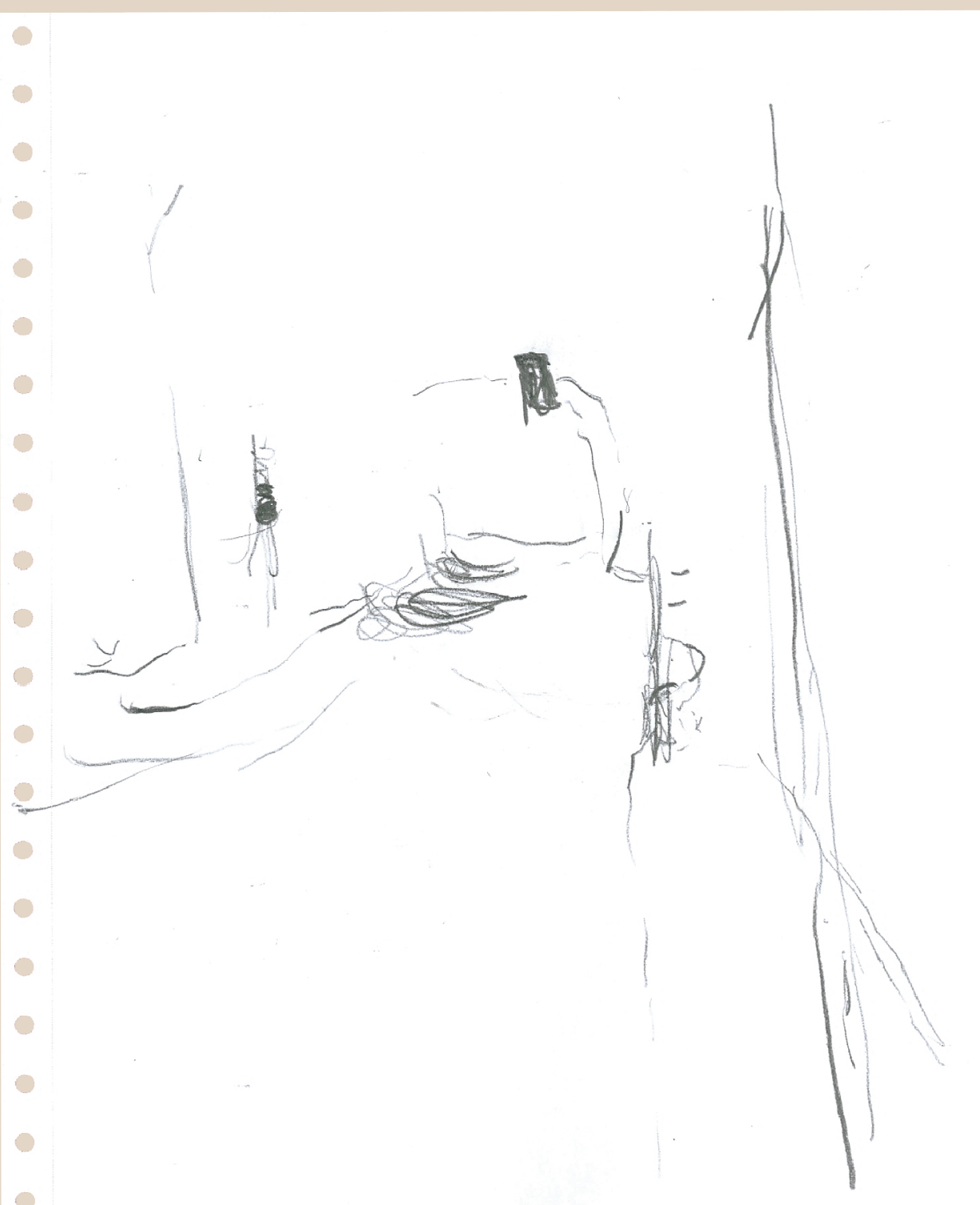


Retorno ao objeto e ao desejo de sua permanência num projeto fadado ao fracasso. Mas o que é a continuidade do trabalho senão a consciência da impossibilidade de retenção das impressões que os fatos, objetos e eventos nos causam? 

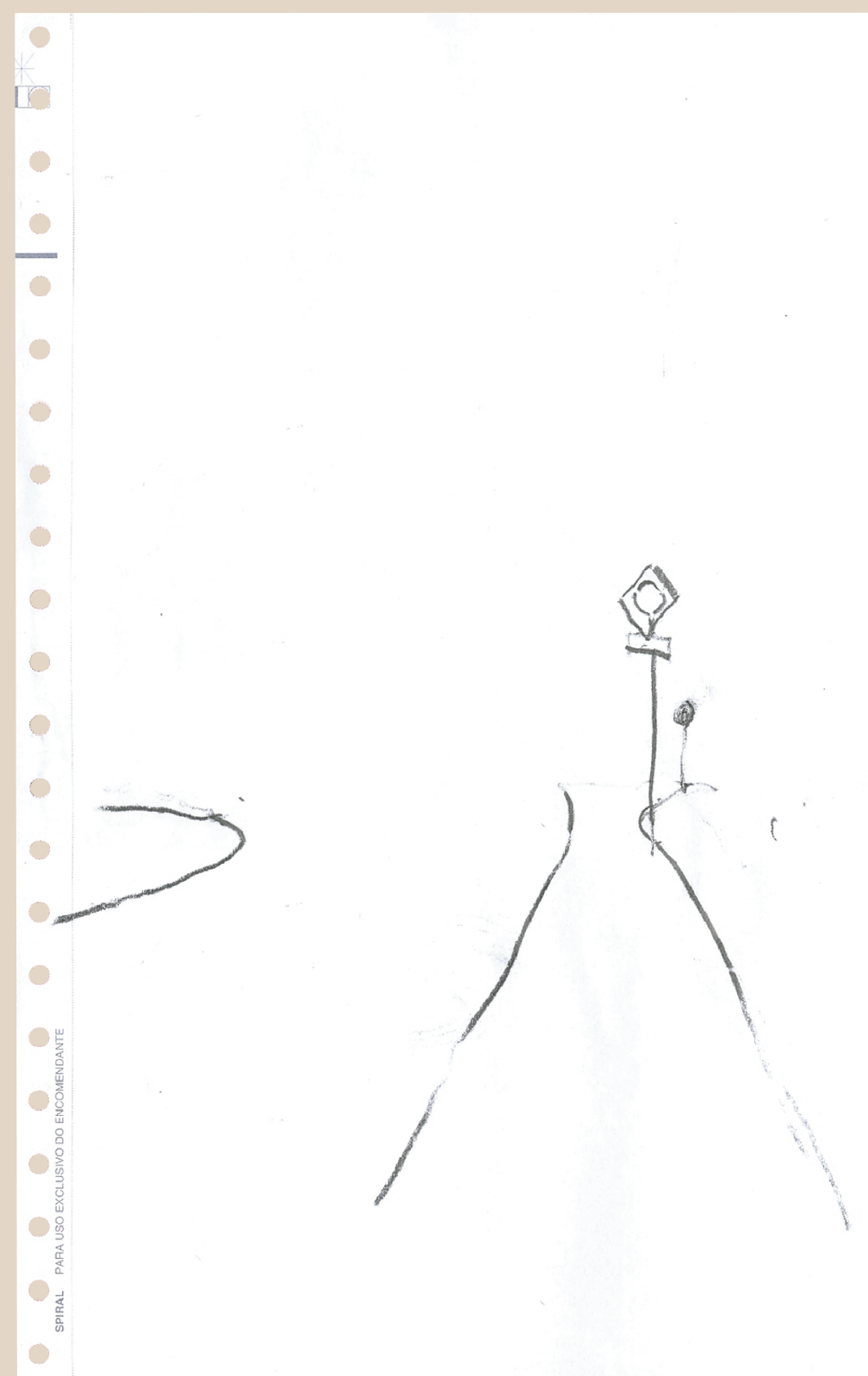
<smiles>C=C(C)C</smiles> 


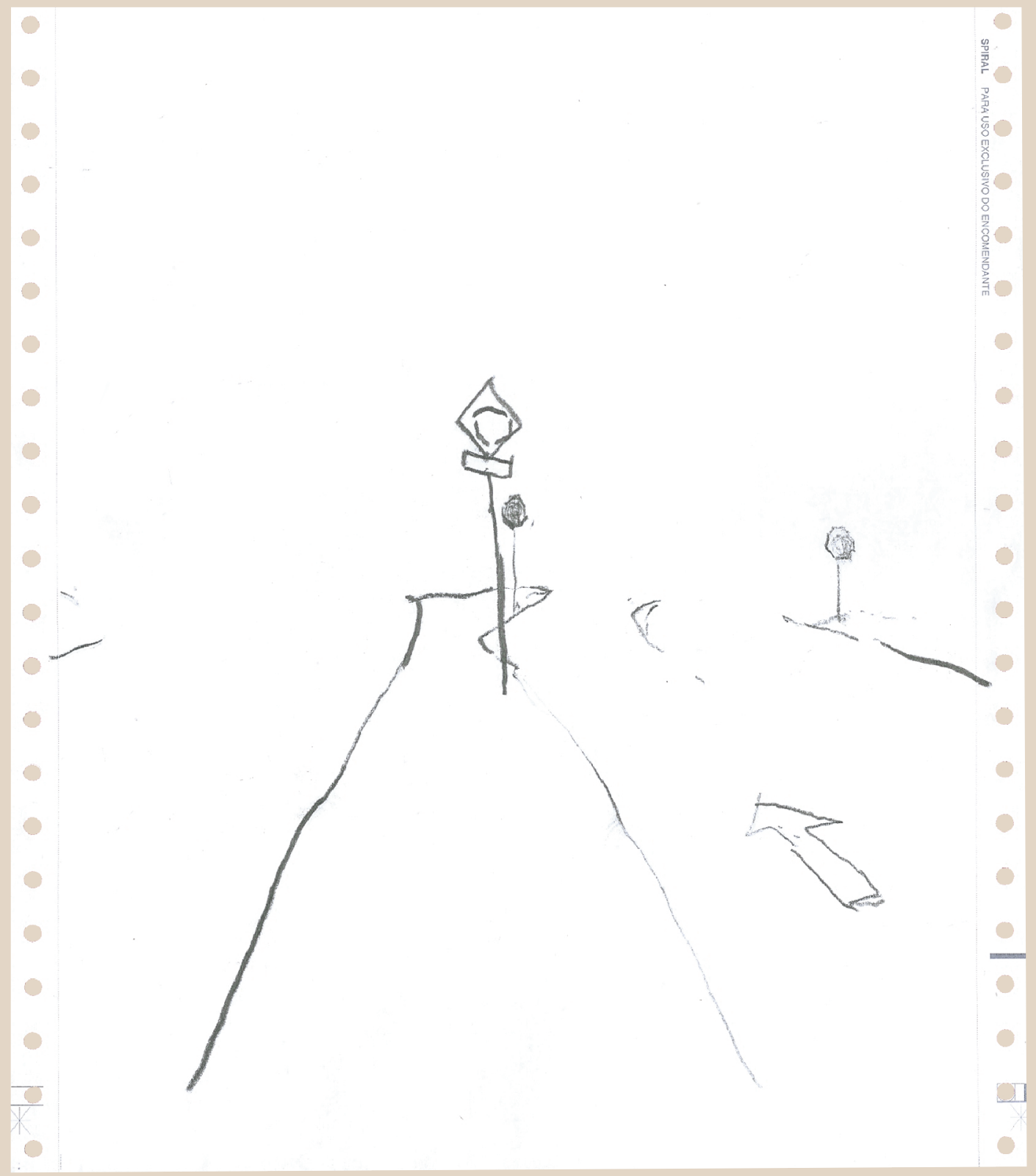




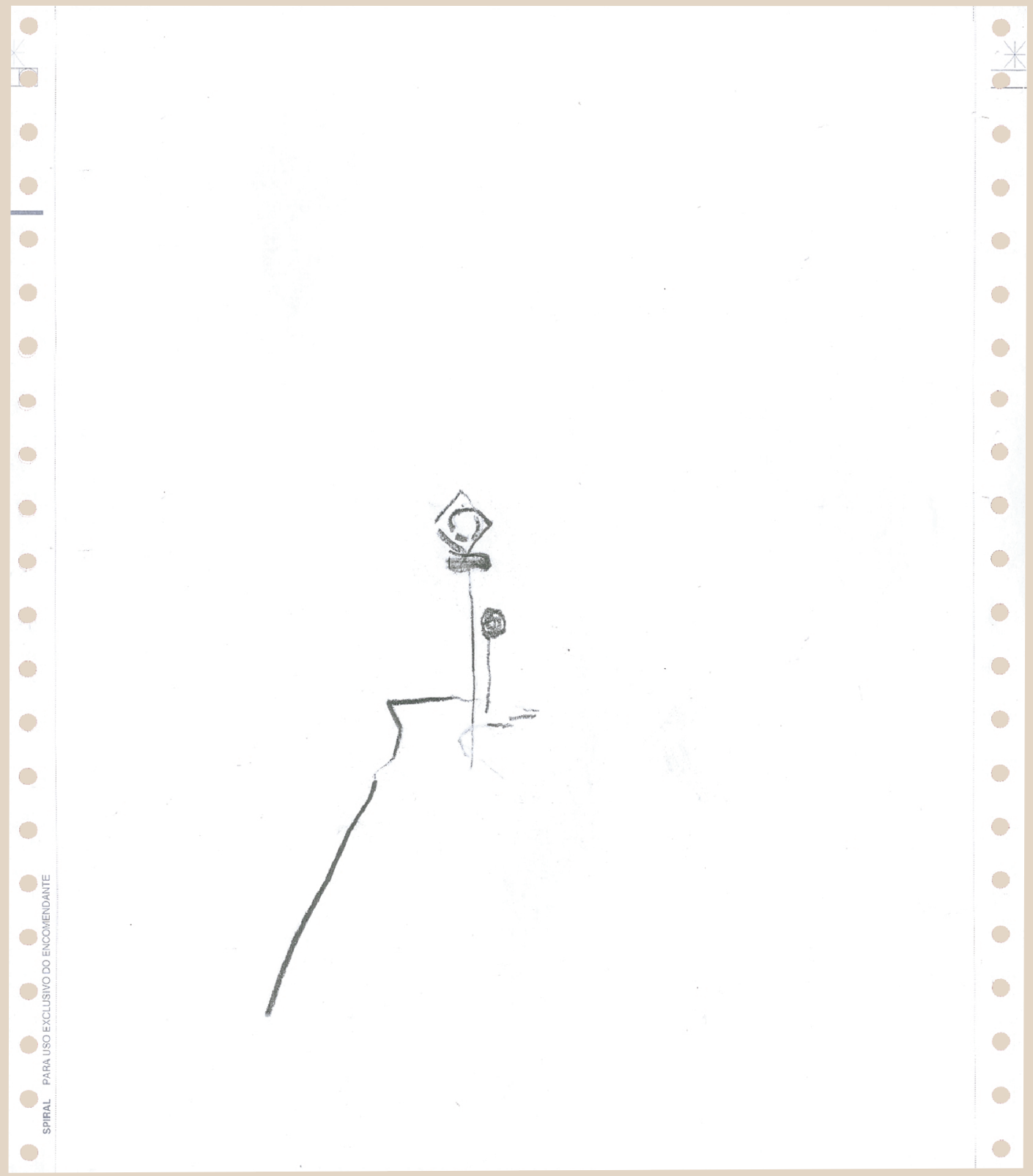


1.4 ...inevitavelmente volto a Cézanne. 
CÉZANNE 

Meu desejo é preservar algum frescor ao atualizar minha relação com a paisagem e seus objetos constitutivos como percebo nas estruturas desenvolvidas por Cézanne. Sua insistência em retornar aos mesmos objetos, por novos pontos de vista, cria uma aparência qualificada para o visível, como se observássemos através de seus trabalhos, sua constituição em andamento.

O artista investiu na instabilidade dos contornos fazendo oscilar a relação figura fundo, nas perspectivas estranhas que planificam o espaço, no jogo entre a opacidade do plano da tela e as transparências aplicadas que articulam volumes e perspectivas. Como resultado nos ofereceu a atualização da percepção com objetos precisamente ficcionados e que fazem o olhar se recompor diante da evidência de estar sendo enganado. Ao escolher temas tão banais e tratá-los sem virtuosismo, investigando-os em direções múltiplas, tornou o que seria óbvio, cenário de estranhezas.

Observar seu trabalho acentuou minha atenção para as articulações espaciais que determinam a presença de cada objeto no desenho. 
"O mundo dos objetos que Cézanne perseguiu e nos revelou em toda a sua multiplicidade, sinceridade e pungência não poderia deixar mais claro sua inerente natureza contrafactual. É um horizonte de significado, uma alternativa à experiência, um contentamento com a não identidade. Ninguém está dizendo, muito menos eu, que esse contentamento poderia ser vivenciado mais que esporadicamente".

(CLARK, 2007, p. 83) 
Em Cézanne há ainda algo da ordem do não dito, do que ainda não se constitui em discurso. As imagens funcionam a partir da junção de peças sem sentido restrito ou determinado pelo seu uso comum, e apontam exclusivamente para elas mesmas, tencionando o que pudesse ser indicação de uso cotidiano. A figura não preexiste, vai sendo remontada por partes, a medida que chamam a atenção do artista. Não existe o motivo antes da experiência, não existe um clima geral dando ao trabalho uma característica específica. O enfrentamento da paisagem gera uma nova paisagem. A memória não é o lugar que se visita na resolução dos trabalhos, tudo parece ser testado na presença daquilo que se apresenta como objeto. O desequilíbrio determinado pela atração que as partes exercem entre si, gera vias de acesso insuspeitas. Perde-se a ideia de visão geral, as partes indicam a cegueira tateante em que vivia o artista. 
O que significa PARE, ou os sinais VIRE À DIREITA, VIRE À ESQUERDA diante das dimensões infinitas possiveis? 
T. J. Clark, em seu ensaio "Fenomenalidade e materialidade em Cézanne", declara perceber elementos de corporeidade na obra "Montanha Sainte-Victoire vista do Château Noir", de 1904: "Há membros, nádegas, coxas, talvez seios, um monte de Vênus com pelos pubianos escuros" (CLARK, 2007, p. 68). Essa sugestão de leitura pode ser percebida na constituição incisiva da montanha de Cézanne. Entendo entretanto que não pode ser confundida com uma experiência de devaneio; em Cézanne, o que está em jogo é o deslocamento da experiência. A liberdade da recriação se encontra na reestruturação da materialidade da montanha, mesmo sem dar a ela características mais sugestivas de corpo. Clark não está determinando como se deve olhar aquela pintura, está dizendo que há vestígios de outras imagens dentro daquela imagem específica e que esse dado nem sempre é claro, sob o risco de se limitar o ato perceptivo. Esse deslocamento interessa no presente trabalho, considerando que, nos meus desenhos, as partes registradas e a maneira como o são ativam não uma única imagem específica mas desestabilizam o modo como as imagens são constituídas. 
Em Cézanne, a parecença entre figura e fundo valoriza, ou desvaloriza ambos igualmente. Há um apagamento que refaz o objeto ou modelo sem tentar, por semelhança de aparência, ser objeto ou modelo, sem enganar um observador, seduzindo-o com uma imagem especular. Nessa operação, a pintura reconstitui a realidade por ângulos inesperados e pelos estranhamentos que se estabelecem entre as partes. 
Paul Cézanne

A curva na estrada em La Roche-Guyon, 1885 óleo sobre tela - $64.2 \times 80 \mathrm{~cm}$

Smith College Museum of Art Northampton, Massachusetts

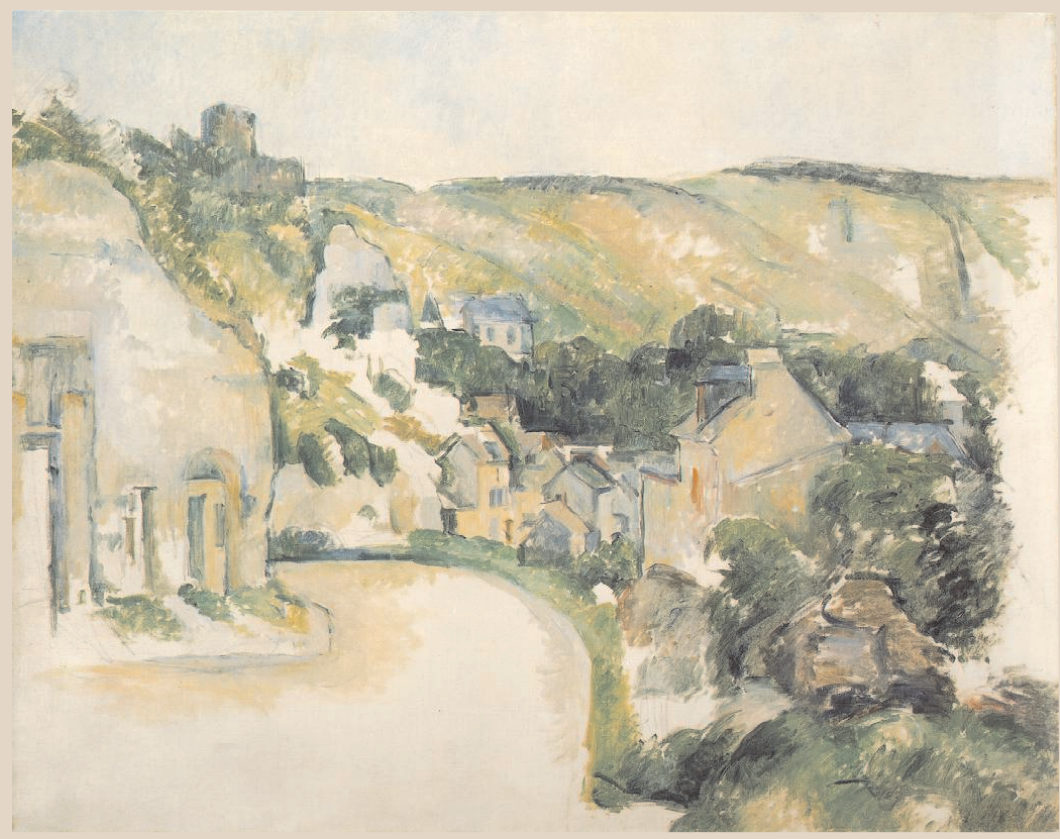


As vias de acesso mudam, alternando o foco dos objetos para o espaço e vice versa. 0 que me interessa é constituir um trajeto, um outro trajeto, como imagino que funcionam minhas ruazinhas, para um movimento perceptivo. Estou atrás daquilo que revigore a importância do que é próximo, essa é a intenção primeira do meu desenho. Trato do próximo e identifico nele o estranhamento inicial, o estranhamento de que lanço mão, e que me serve, paradoxalmente, como ancoragem para renovar o caminho percorrido naquilo que vejo.

Nos meus arranjos compositivos intuitivos, quando me deixo orientar pela proximidade dos objetos, por mais que me pareçam infantis, é através deles que entendo Cézanne, que meu trabalho atesta suas heranças. Através desta espécie de caligrafia que outros nomes, além do meu, surgem: Cézanne, Mira Schendel, Klee, meu pai, os sítios onde minha família viveu, Morandi. 
2.9

Paul Cézanne

Natureza morta (tijela e jarro de leite), c.1873-7 óleo sobre tela - $20 \times 18 \mathrm{~cm}$ Bridgestone Museum of Art, Fundação Ishibashi, Tóquio

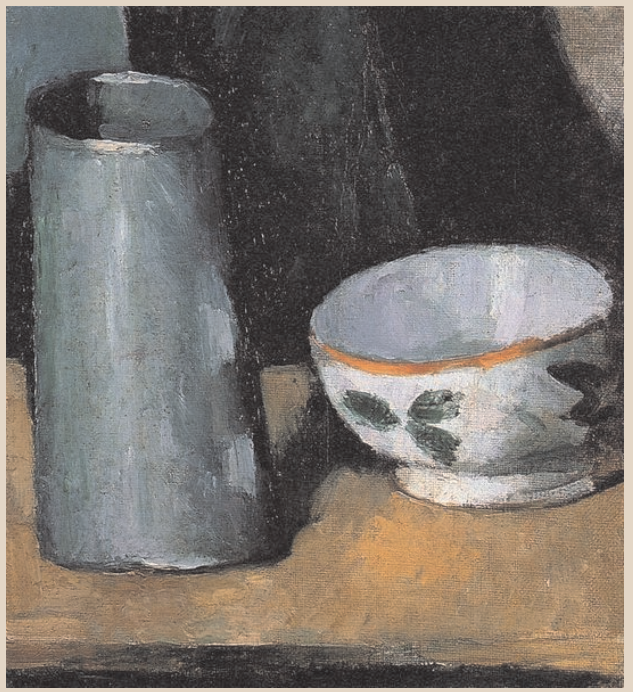


Nas ruas, minhas percepções geram uma organização que parece fazer do espaço uma geléia, mantida estável graças à maneira como estão dispostos os detalhes que me chamam a atenção. Os resultados, que vejo nos desenhos, apontam para o dado visível, primariamente visivel, imediato, que ao mesmo tempo me afeta e constitui o cenário desta afetação. As paisagens geram uma solidão de um mundo vazio e mantêm algo de primitivo, no sentido em que a sofisticação é física, não instrumentada ou mediada; acontece na relação com a paisagem, presencialmente, e não no manuseio de instrumentos que permitam ilustrar o que vivi nela. 
Paul Cézanne

Curva na estrada, 1900-06 óleo sobre tela - $81.3 \times 64.8 \mathrm{~cm}$

Coleção particular

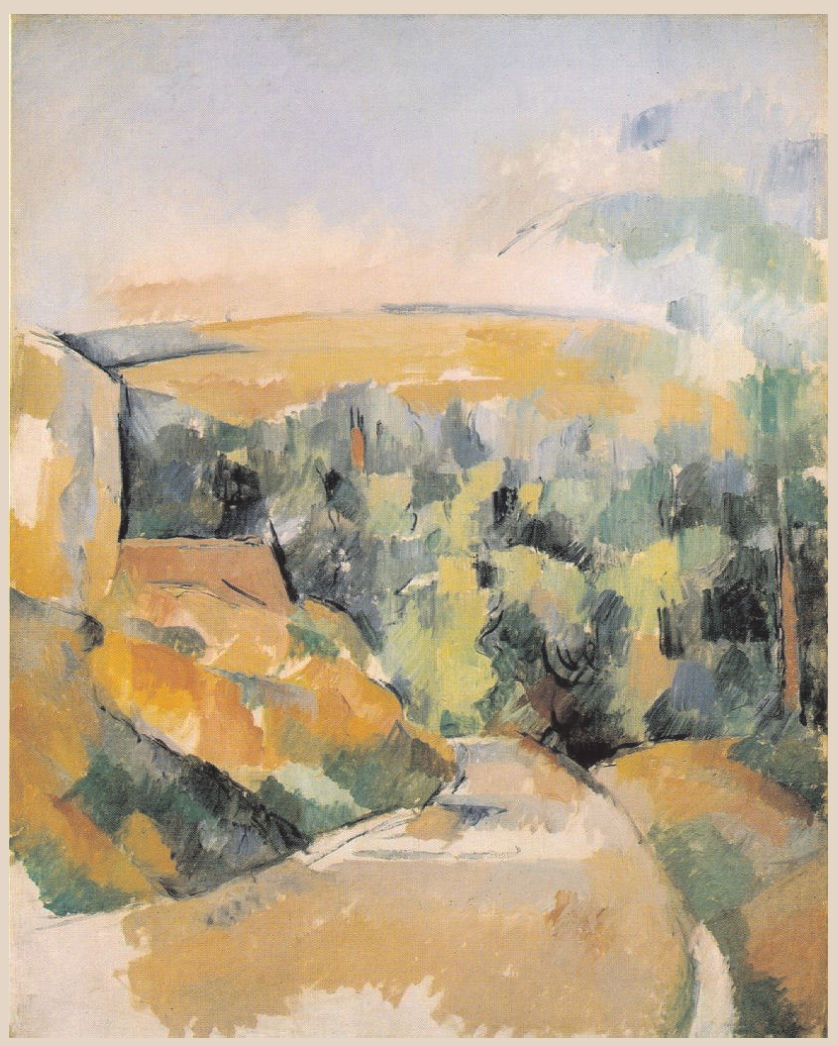




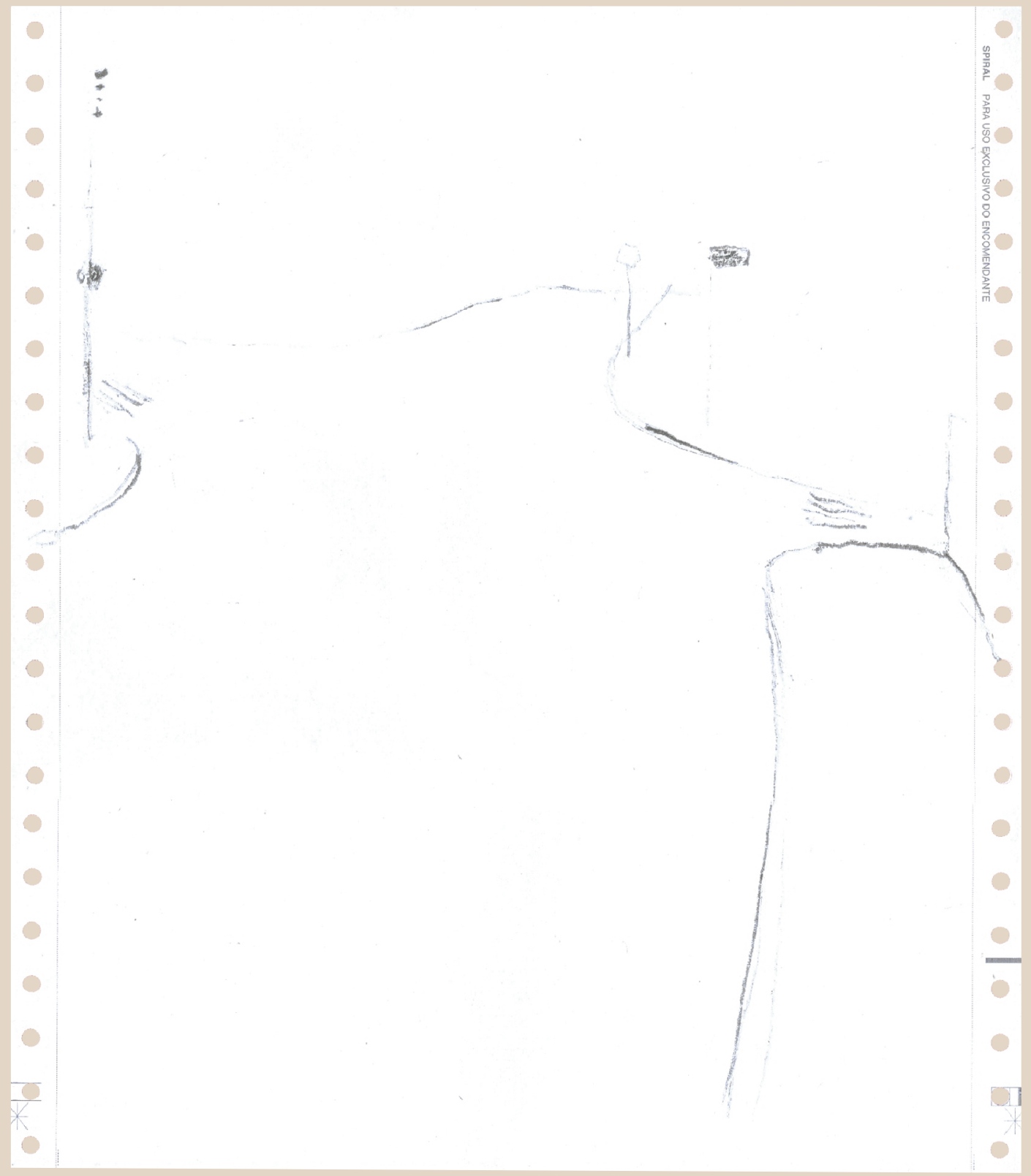




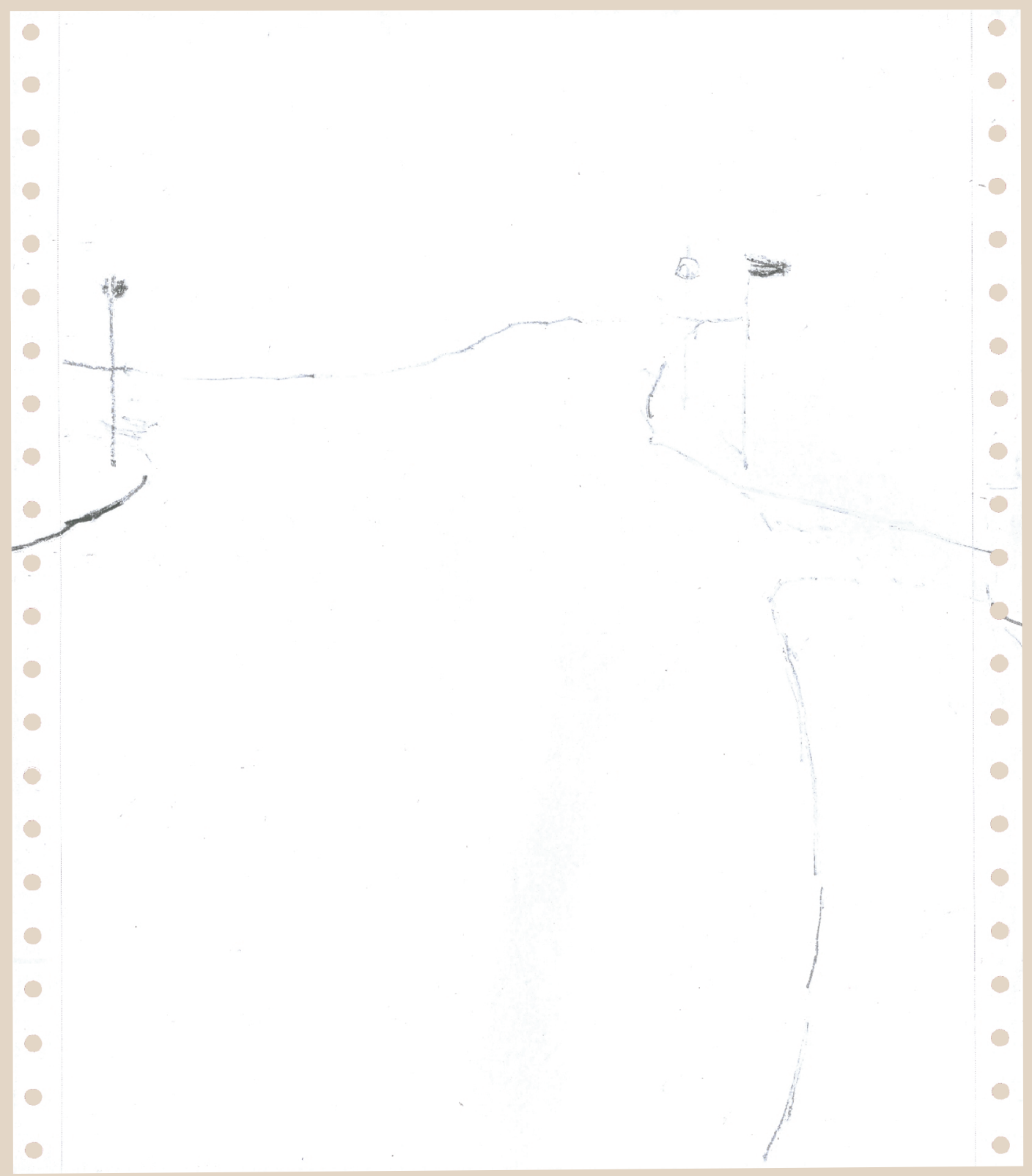




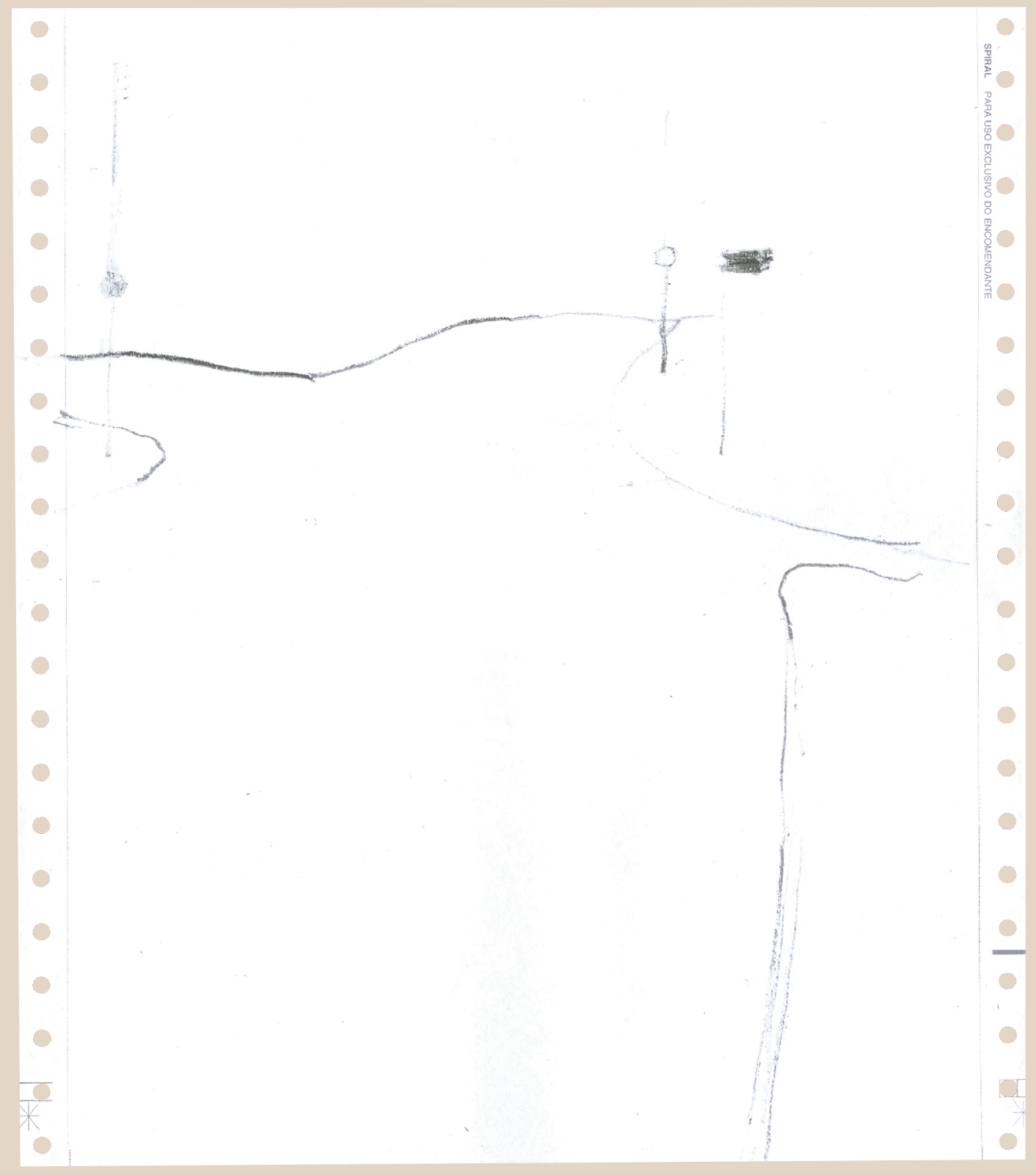




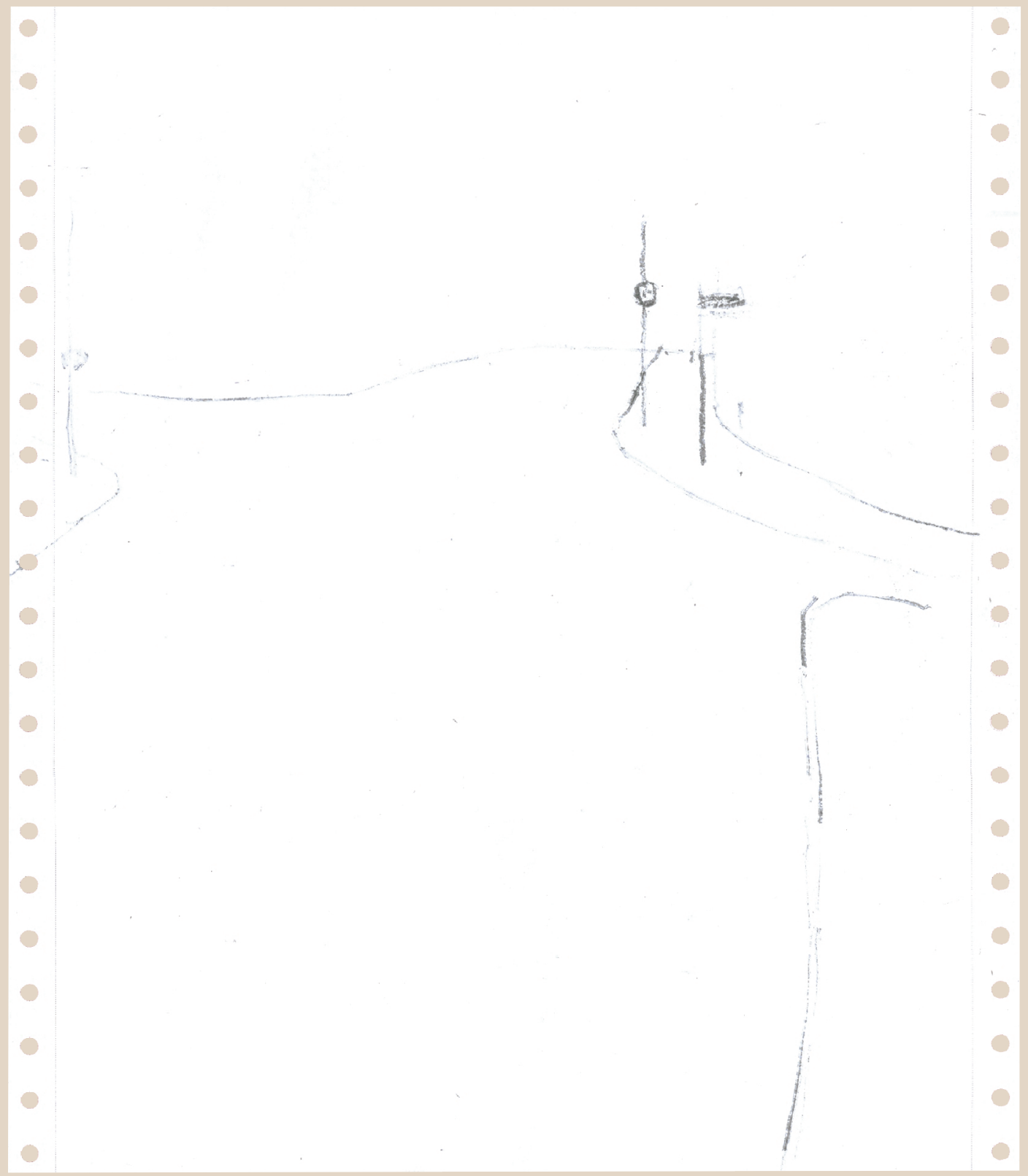


O texto a seguir, de Borges, me faz pensar o que a palavra paisagem nomeia, em como há a transferência de características da paisagem para diferentes superfícies, em como a paisagem se deixa saber por ângulos imprevistos, através de movimentos aparentemente sem sentido do lápis arranhando o papel. Paisagem é uma sugestão de direção, torna-se uma superfície impregnada de silêncios em equilíbrio para sugerir um emaranhado de sutilezas. 
"Em Buenos Aires, o Zahir é uma moeda comum de vinte centavos; marcas de navalha ou de canivete riscam as letras N T e o número dois; 1929 é a data gravada no anverso. (Em Guzerat, em fins do século XVIII, um tigre foi Zair; em Java, um cego da mesquita de Surakarta, que os fiéis apedrejavam; na Pérsia, um astrolábio que Nadir Shah mandou atirar no fundo do mar; nas prisões do Mahdi, por volta de 1892, uma pequena bússola que Rudolf Carl Von Slatin tocou, envolta numa dobra de turbante; na mesquita de Córdoba, segundo Zotembeg, um veio no mármore de um dos mil e duzentos pilares; entre os judeus de Tetuan, o fundo de um poço.) Hoje é 13 de novembro; no dia 7 de junho, de madrugada, chegou às minhas mãos o Zahir; não sou o que então eu era; mas ainda me é dado recordar, e talvez contar, o ocorrido. Se bem que, parcialmente, ainda sou Borges"(BORGES, 2001, p.109). 
2.14

Os objetos me oferecem uma fresta quando os observo atentamente. 


\subsection{6}

Ao usar artistas como referência, me orientei por um critério muito simples, seus trabalhos me sugerem paisagens em desdobramentos e outras materialidades. Assim penso na Musa Adormecida de Brancusi, no esvaziamento que provoca, desertificando o entorno, em Morandi pelo mesmo motivo, Serra, pela potência horizontalizada no peso de seus trabalhos, De Chirico, pela irregularidade misteriosa do espaço, Goeldi por colocar todas estas sofisticações na rua, à mercê das intempéries, Volpi pela expansão de suas luzes e até Duchamp, pela metáfora perfeita para a vida como um permanente rearranjo de forças, no jogo de xadrez. Penso haver indícios de paisagem em todos eles. 

3.1

Como os objetos se comportam no esquecimento? 
3.2

Goiorgio Morandi

Natureza-morta, 1952

óleo sobre tela - $32 \times 48 \mathrm{~cm}$

Museu Morandi, Bolonha

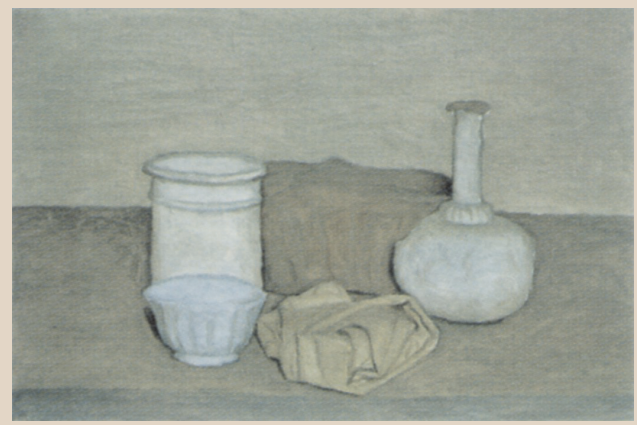


Luzes indiretas recortam objetos em sombras de temperaturas brandas. 
$=$

नI 
A maneira como são tratados os objetos e o espaço em Morandi faz deles entidades de densidade semelhante. As passagens sutis de cores, a imprecisão na definição dos limites fazem o olhar passar de um ao outro sem grandes saltos. O descanso que um objeto oferece ao outro, ou ao espaço contíguo, ou à sua sombra, qualificam, por desdobramento, a presença do próximo. A solidão de deserto que as cores criam colocam todos, objetos, espaço e sombras em um mesmo estado de espera. 
Das lições de Morandi, aprendi a desenhar para testar a qualidade de minha presença, para registrar a horizontalidade do mundo, das relações de proximidade menos hierarquizadas, de significados transferiveis e intercambiáveis. Aprendi que posso desenhar para testar a plasticidade daquilo que vejo. 


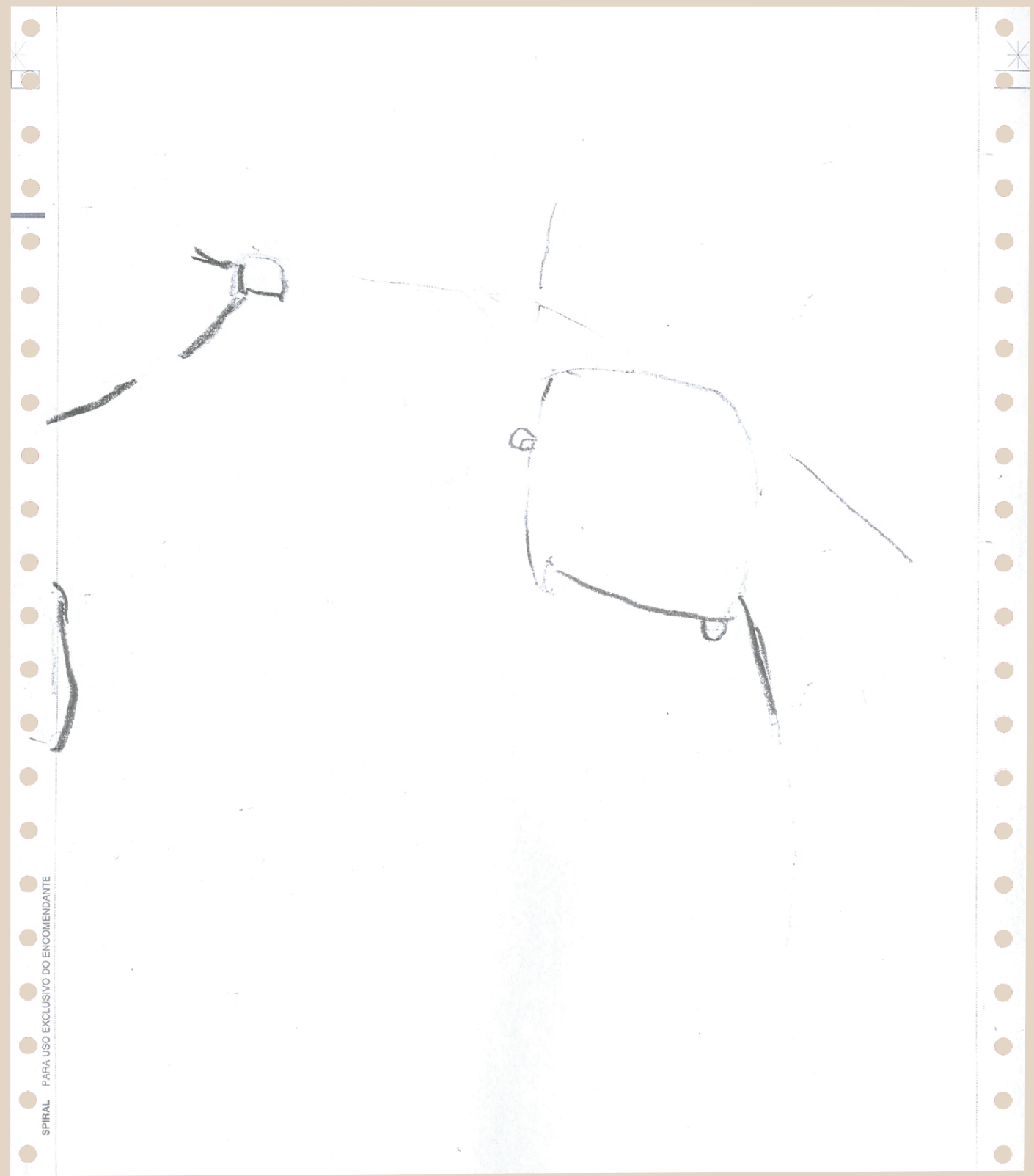




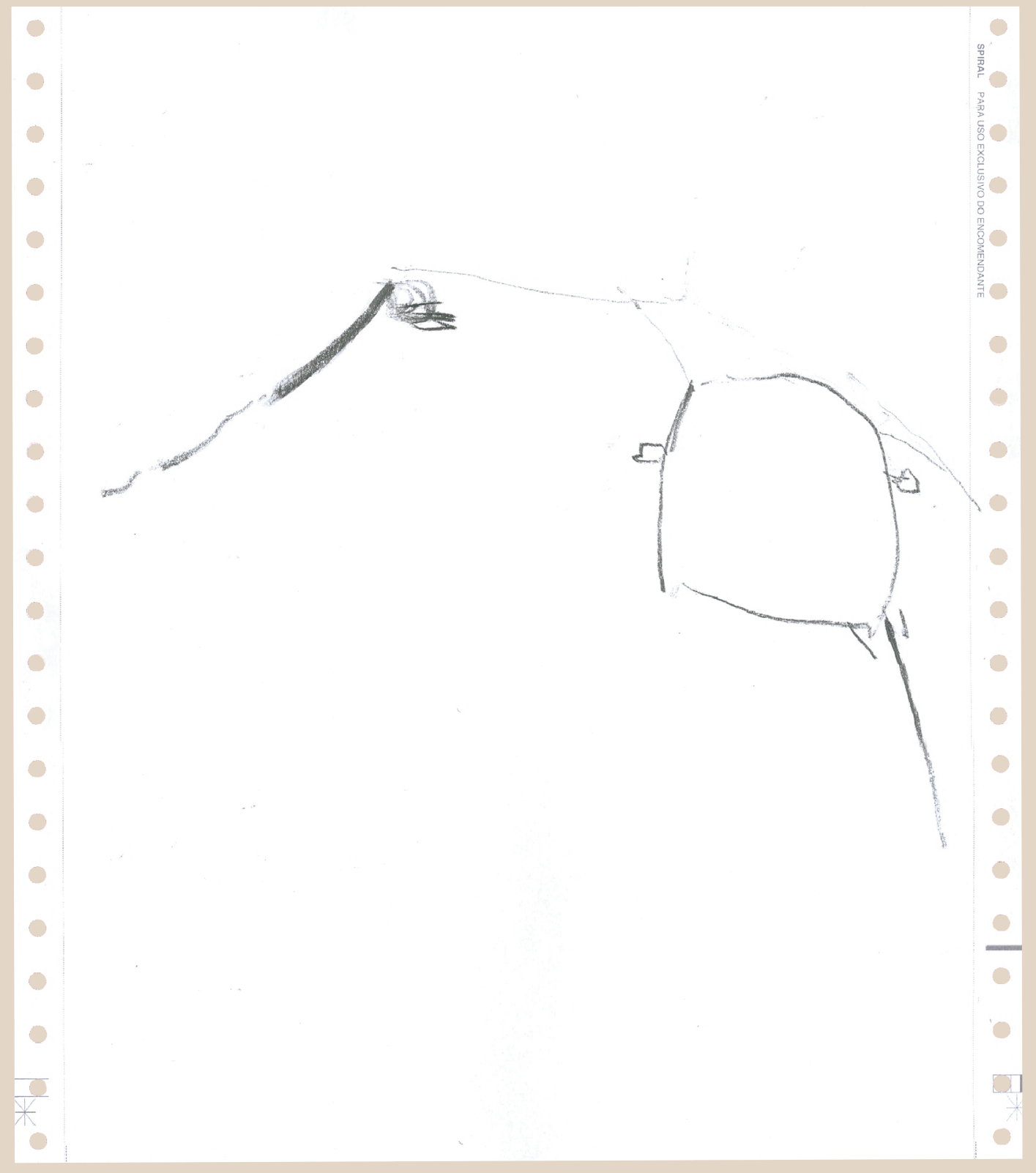




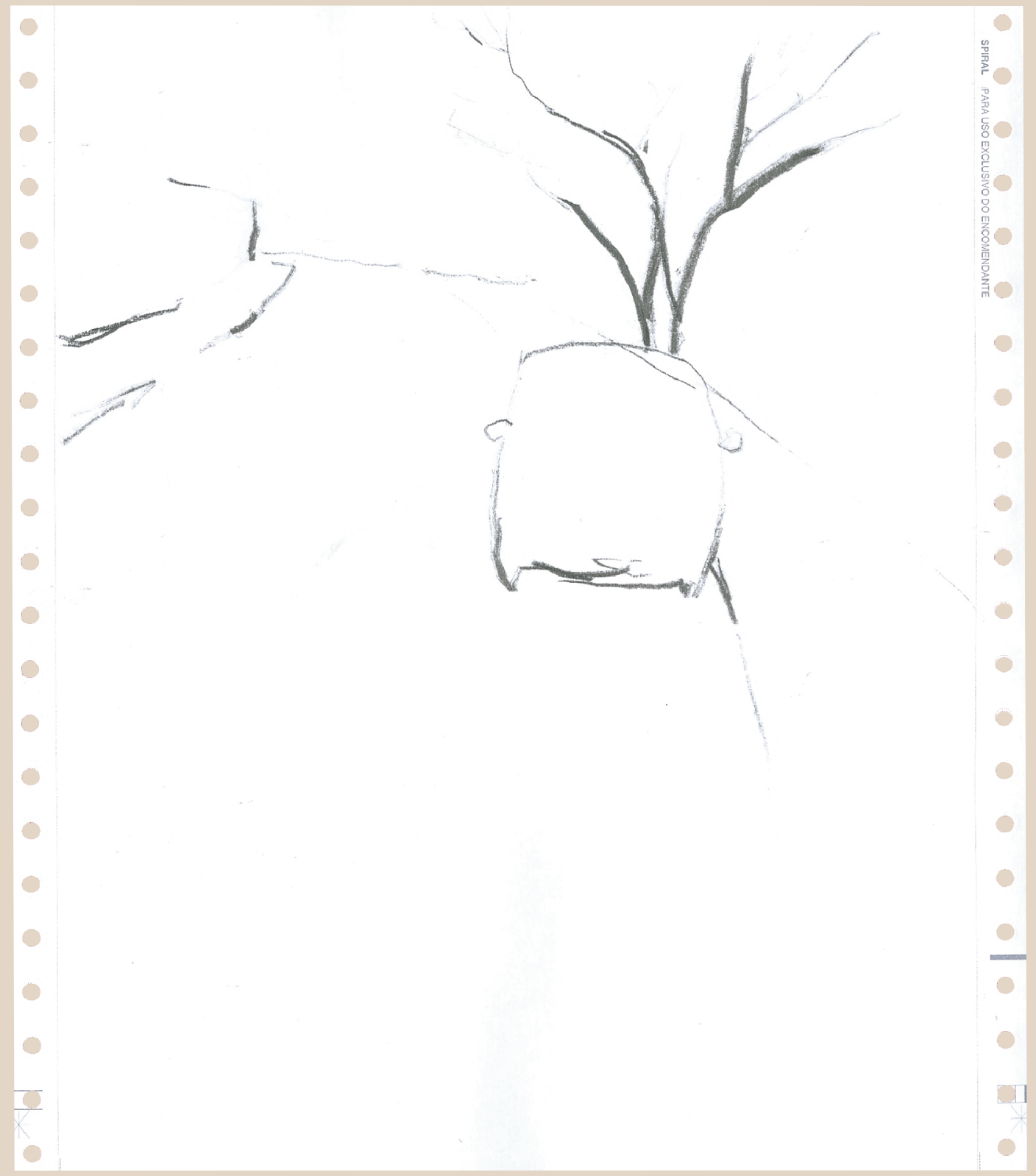




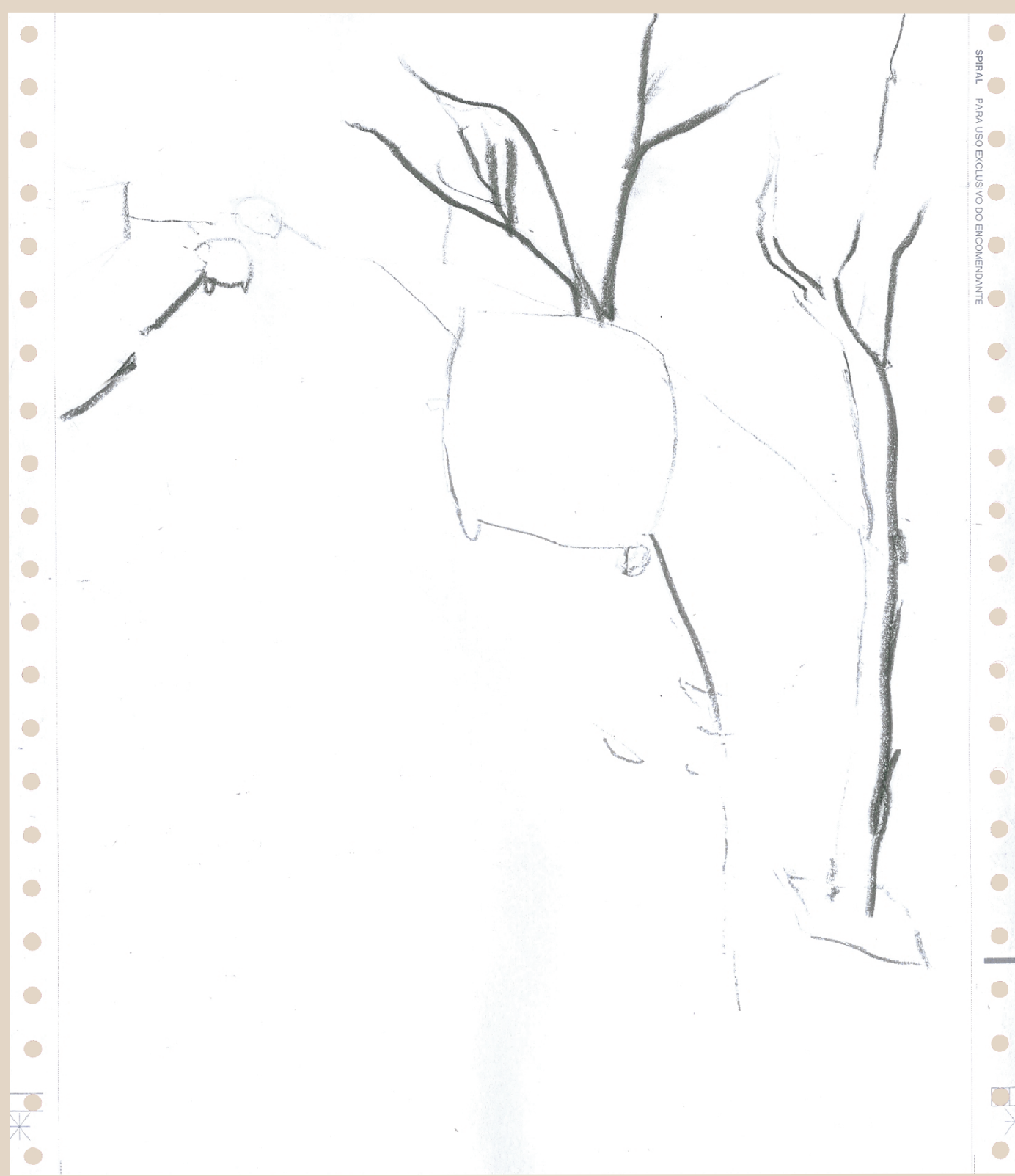


SERRA 

Presença e peso; o movimento heróico gera o objeto que interrompe e reorienta a força da gravidade. 
4.2

Richard Serra

Apoio de uma tonelada (castelo de cartas), 1968-69

placas de chumbo - 139,7 × 139,7 × 139,7 cm

Coleção particular

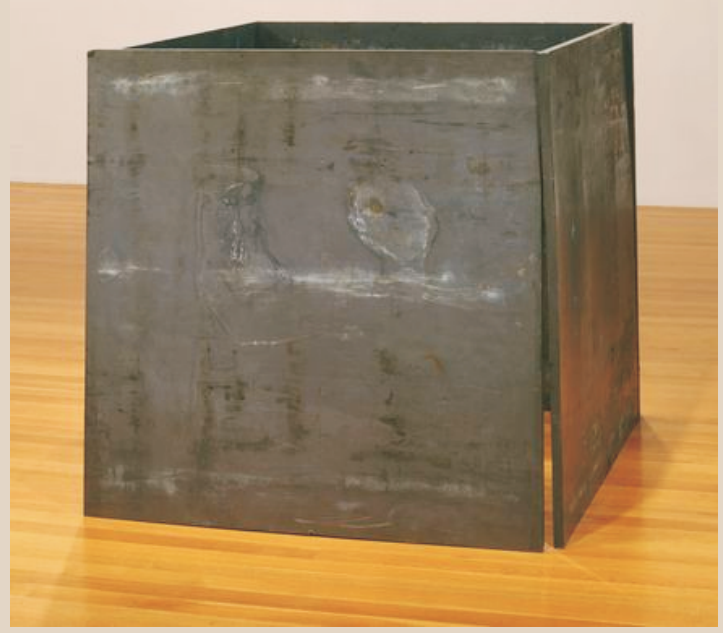


Há um raciocínio plástico em Richard Serra, uma experiência espacial que me interessa: as partes desafiam a inteireza.

A tensão das linhas de sustentação sugere uma nova configuração eminente, um novo arranjo que virá com a queda; o equilíbrio é manifesto na instabilidade, num arranjo simples de planos levemente desequilibrados com presença maciça e desestabilizadora. 
A horizontalidade da paisagem sugerida pelos trabalhos de Serra torna provável encontrar o mesmo objeto, uma segunda vez de um ângulo diferente. Mas a dimensão e abstração de suas peças afetam o espaço e o movimento de quem as encontra, neste caso então, paisagem é um campo de acessos possiveis, de pesos e assentamentos novos a cada momento. 
O espaço essencial - as estruturas essenciais - se constituem no trajeto percorrido. 

BRANCUSI E VITALINO 

Mestre Vitalino

Bois, s/data

cerâmica

Acervo do Museu de Arte Popular do Recife

Constantin Brancusi

Musa adormecida, 1910

bronze dourado - $15,8 \times 28,7 \times 17,1 \mathrm{~cm}$ Museu Nacional de Arte Moderna de Paris
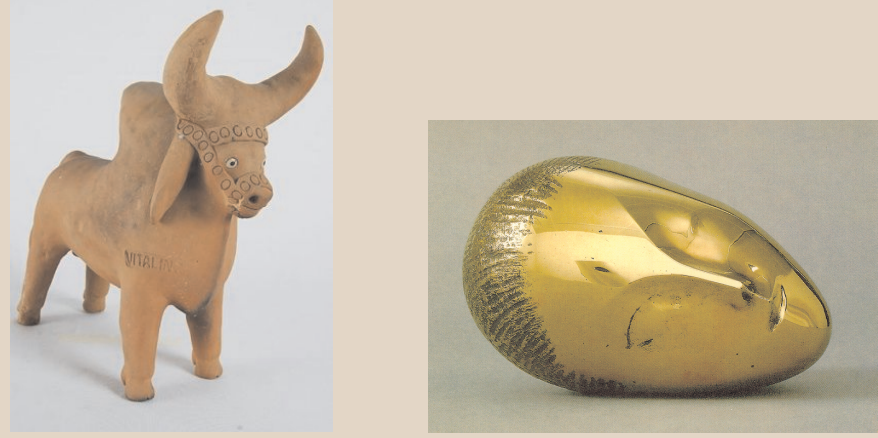
A aproximação proposta pelos trabalhos de Brancusi, me faz entender que eles ali estão para serem tocados, em nudez extrema, em materiais cujo polimento ou o acabamento atraem a mão. Indícios de manufatura sugerem a intimidade de um sujeito com aquelas peças. Os objetos são orientadores de ação, um pássaro sendo impelido a voar, um peixe a nadar. Este sentido de experiência simplificada e assim levada ao extremo, determina a forma e a densidade dos corpos. Esta redução ao mais simples, ao elementar, me lembra o que disse Cézanne: "entender o mundo a partir do cubo, da esfera e do cilindro" como articulações do mesmo, partes interdependentes, transmutáveis entre si, um dado que está na experiência presencial que familiariza e por isso mesmo se organiza em aparência mais simples. Neste sentido, é possível aproximar Brancusi da sofisticação de um Mestre Vitalino. 
Ao observar carros na rua percebo essa força emblemática da Musa Adormecida de Brancusi, ou dos bois de Mestre Vitalino, aparentemente paralizados e fora de linha. Sua presença é obsoleta e envelhecer, de certa forma, os torna atemporais. O colorido gasto dos carros velhos, como um deserto, indica a superfície mínima de um esvaziamento; um pouco mais densa que o entorno, dá forma a energias primárias submetendo-as ao tempo. 

DE CHIRICO 

Sou parte das estruturas que não vejo. Tento reconstituir espaços que funcionem como passagem por onde qualidades de paisagem entrem. 
6.2

Giorgio De Chirico

The Anxious Journey, 1913-14

óleo sobre tela - $74 \times 107 \mathrm{~cm}$

The Museum of Modern Art, New York

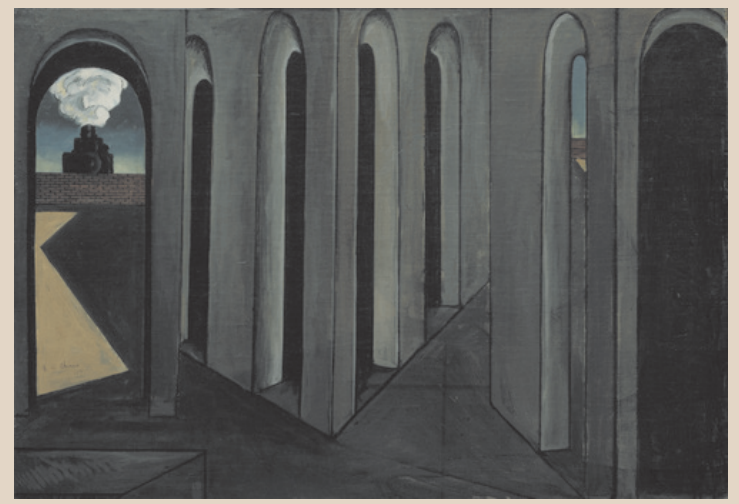


De Chirico força a experiência a uma atualização permanente. Suas paisagens tem distanciamentos improváveis no tempo e no espaço que qualificam o erro perceptivo, o que se vê não é o que se vê, somos induzidos ao auto-engano, pegos no labirinto que é nossa necessidade de produção de sentido.

Suas paisagens são resíduos de passado ou de futuro? 
6.4

Quando desenho, me torno cenário para aquilo a que dou as costas. 
São sempre percepções parciais dos objetos, mas também aos objetos são oferecidas percepções parciais a meu respeito. Ao realocar os objetos, nos desenhos, surgem dúvidas quanto às evidências sobre o estado da realidade. 
O que não é visível de um ponto, é visível de um outro distante e não visível do primeiro e assim por diante. Me interessam as percepções parciais. 

ocultamento. 
O sentido destes desenhos é o vazio no centro de um vórtice que torna os eventos e objetos imprecisos. 
VOLPI E GOELDI 


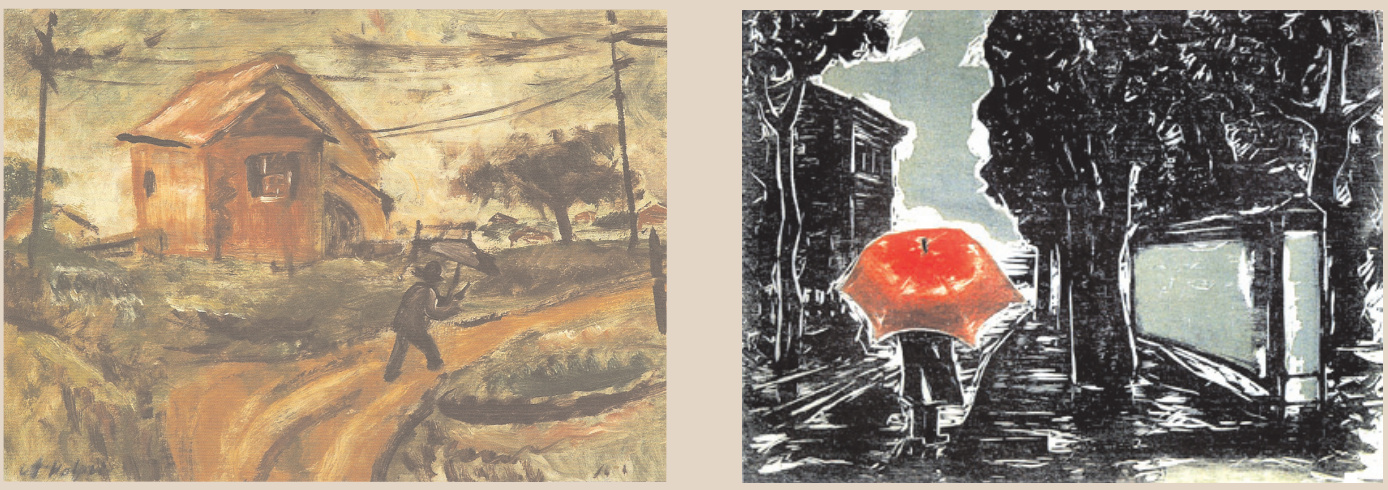
Nestes trabalhos de Volpi e Goeldi, o dado natural se cola à superfície a que eles chegam, se confunde em qualidades específicas: terras em Volpi e umidades em Goeldi. Mostram a gravidade de um dia chuvoso e as qualidades dos dias comuns. Também observo esses aspectos e experiencio a liberdade ao realizar um desenho. 
A paisagem é uma rota de fuga, pode ser vista ou sentida; pode-se caminhar através dela ou nela se recolher. 
7.4

Os elementos da paisagem, a maneira como são tratadas as materialidades, refletem sua sujeição às intempéries. 



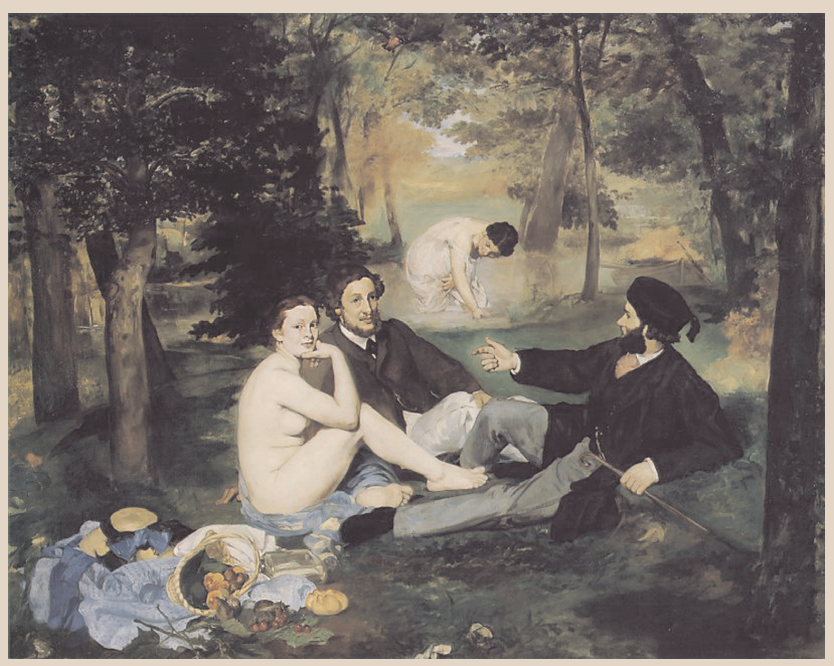


Um pequeno pássaro (um pardal?) na parte superior da pintura de Manet ocupa o lugar normalmente destinado ao espírito santo em pinturas religiosas. O ordinário ocupa o lugar do sagrado em um novo arranjo de peças disponíveis para atualizar um conteúdo. A paisagem acolhe os mais diversos arranjos. A ATUALIZAÇÃO implica em EQUIVALÊNCIAS e consequentemente em RELATIVIZAÇÃO DE VALORES. 
Minhas pequenas paisagens constituem o trajeto por onde o que entendo por sofisticação me chega. As qualidades das linhas e das cores referem-se à uma paisagem de aparência simples. Entretanto, sinto que algo nelas vibra e abre outras entradas por ângulos diferentes. Sou afetado por qualidades de um espaço instável de profundidade variável onde os objetos constituem um drama singular: são sinalizações estáveis de espaços imprecisos. 

MATERIAIS, UM QUASE NADA 

O material é o primeiro indício dos resultados que procuro. Com papéis baratos, que podem ser adquiridos em grande quantidade posso desenhar e errar muito, tudo pode ser refeito. O que acontece é que crio intimidade com o material escolhido que assim passa a acrescentar qualidades que se tornam estruturais no meu trabalho, o que era simplesmente ordinário, passa a ser necessariamente ordinário. 
Os materiais me comprometem ao me oferecerem condições de conexão; quanto mais simples forem, melhor. Há algo não lógico em seu uso e parte do que virá a ser consciência manifesta no trabalho está dispersa neles. 
"Em vez de resolver seu problema - 'seu', porque foi ele que o escolheu -, o artista vive esse problema através da instrumentalidade dos seus materiais. Fixando seu pensamento no material, o artista põe a nu seja a falta de sutileza de sua ideia, seja a falta de apuro de sua arte, e isso o induz a experimentar e aperfeiçoar-se. Mais cedo ou mais tarde, ele se torna tão habilidoso na materialidade de suas ideias, e no manejo dos materiais como se fossem pensamentos, que a dificuldade, em si, é transformada: o artista traduziu o problema em um conjunto ímpar de termos. Além disso, o próprio artista, o pesquisador, se transforma, por seus esforços, em um homem diferente" (ROSENBERG, 2001, p.23/4). 


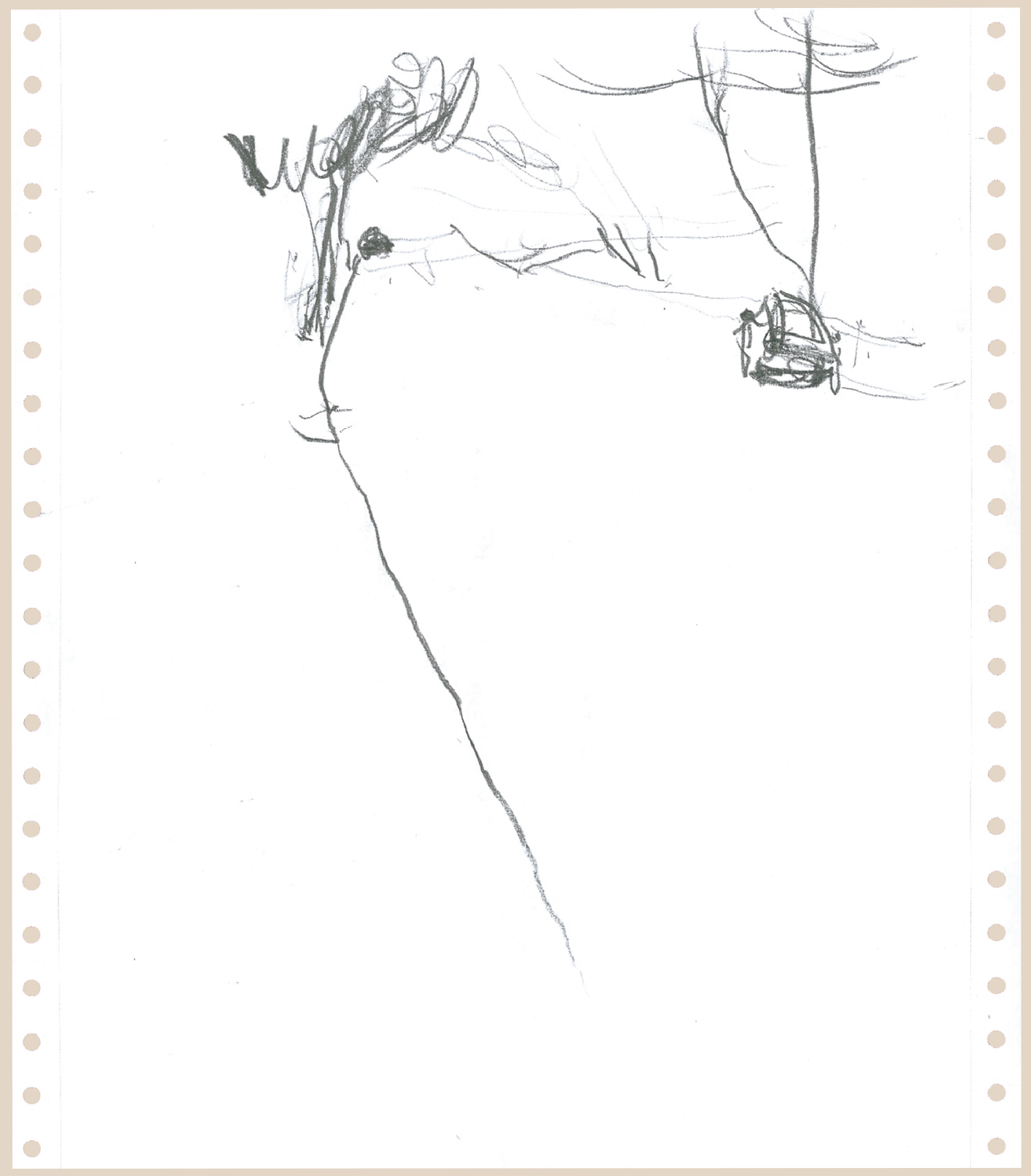


OS OBJETOS 

Fico atento a carros velhos, suas superfícies gastas, linhas antiquadas e cores fora de época, à beleza da passagem do tempo. 


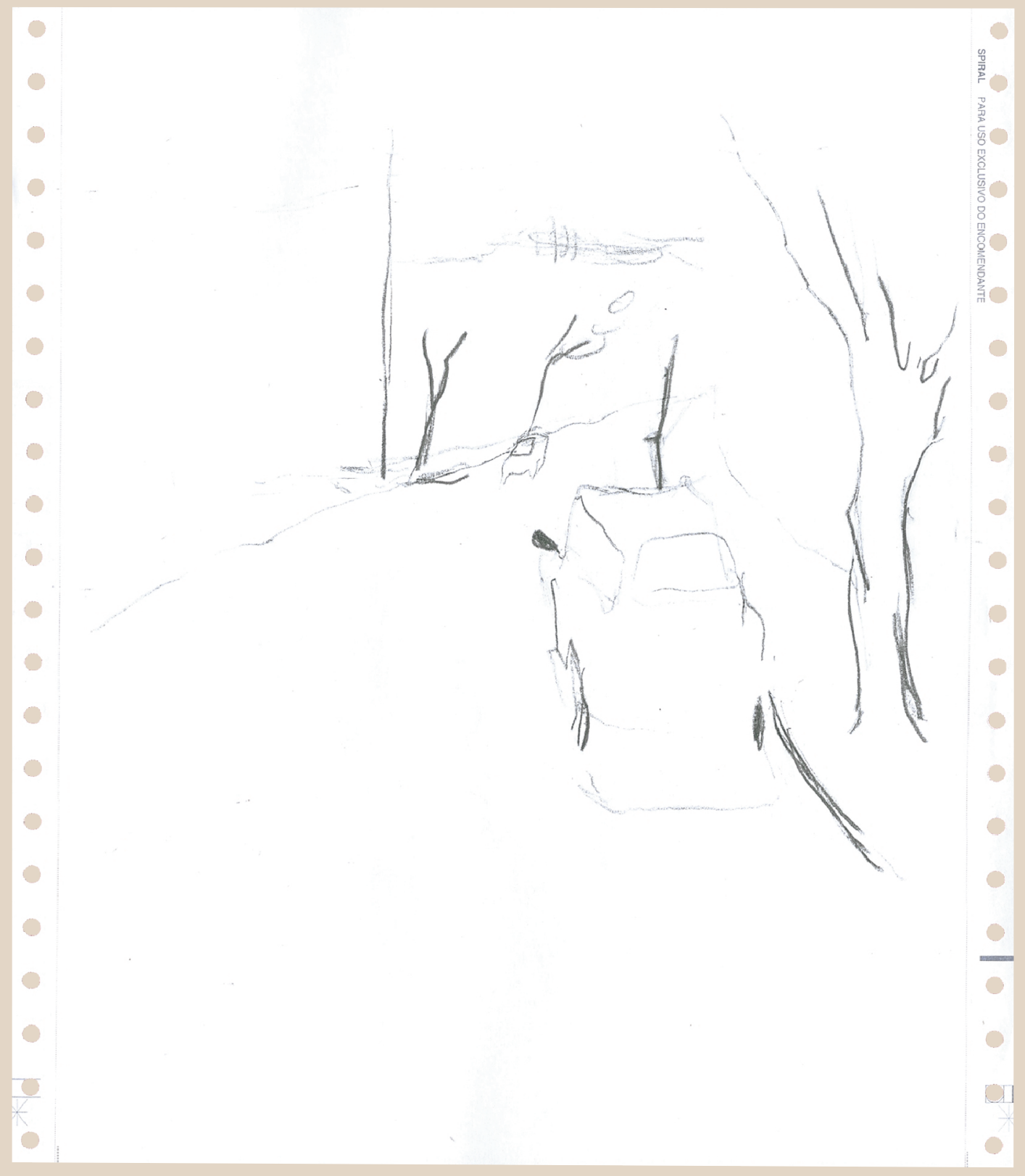




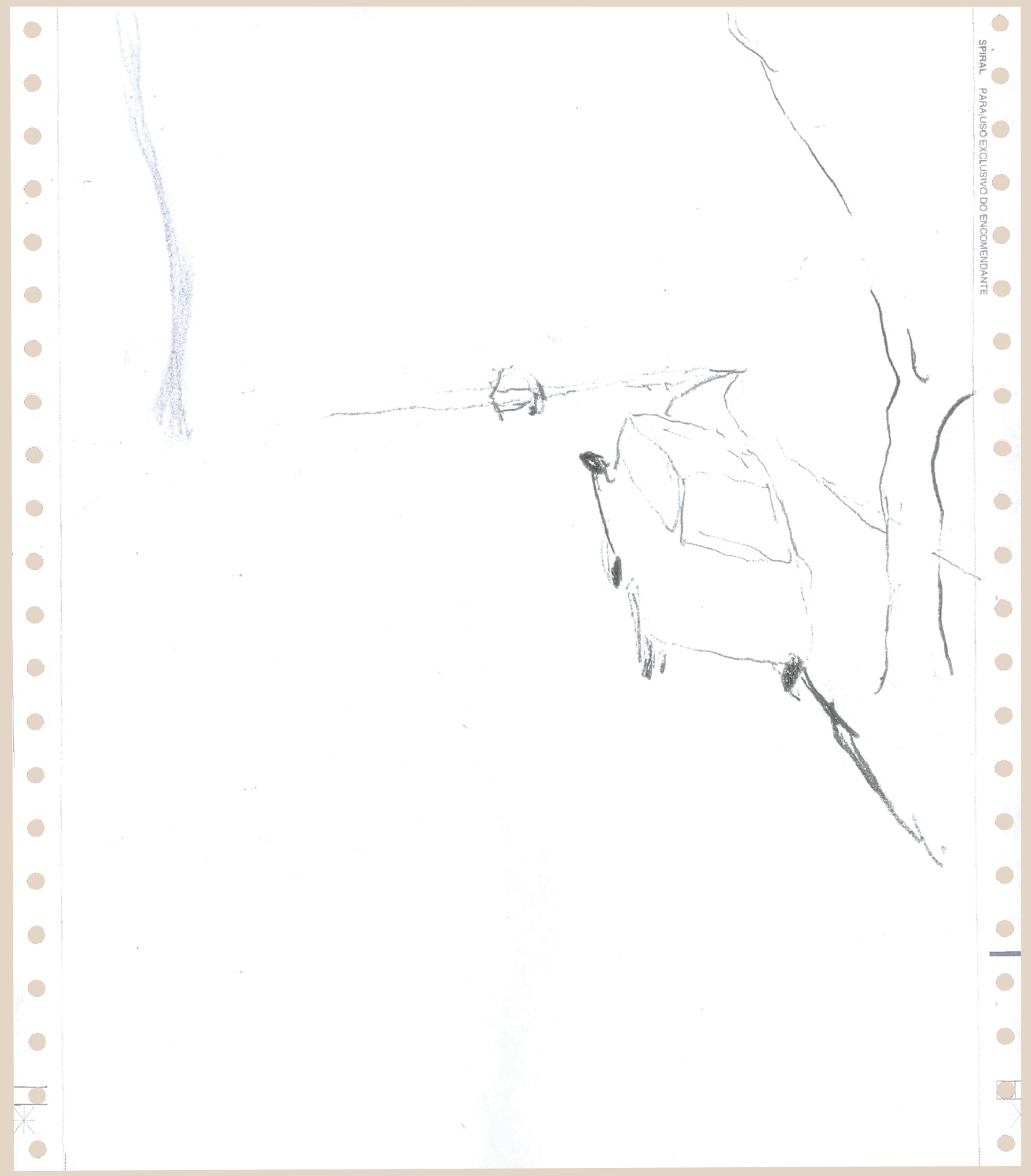




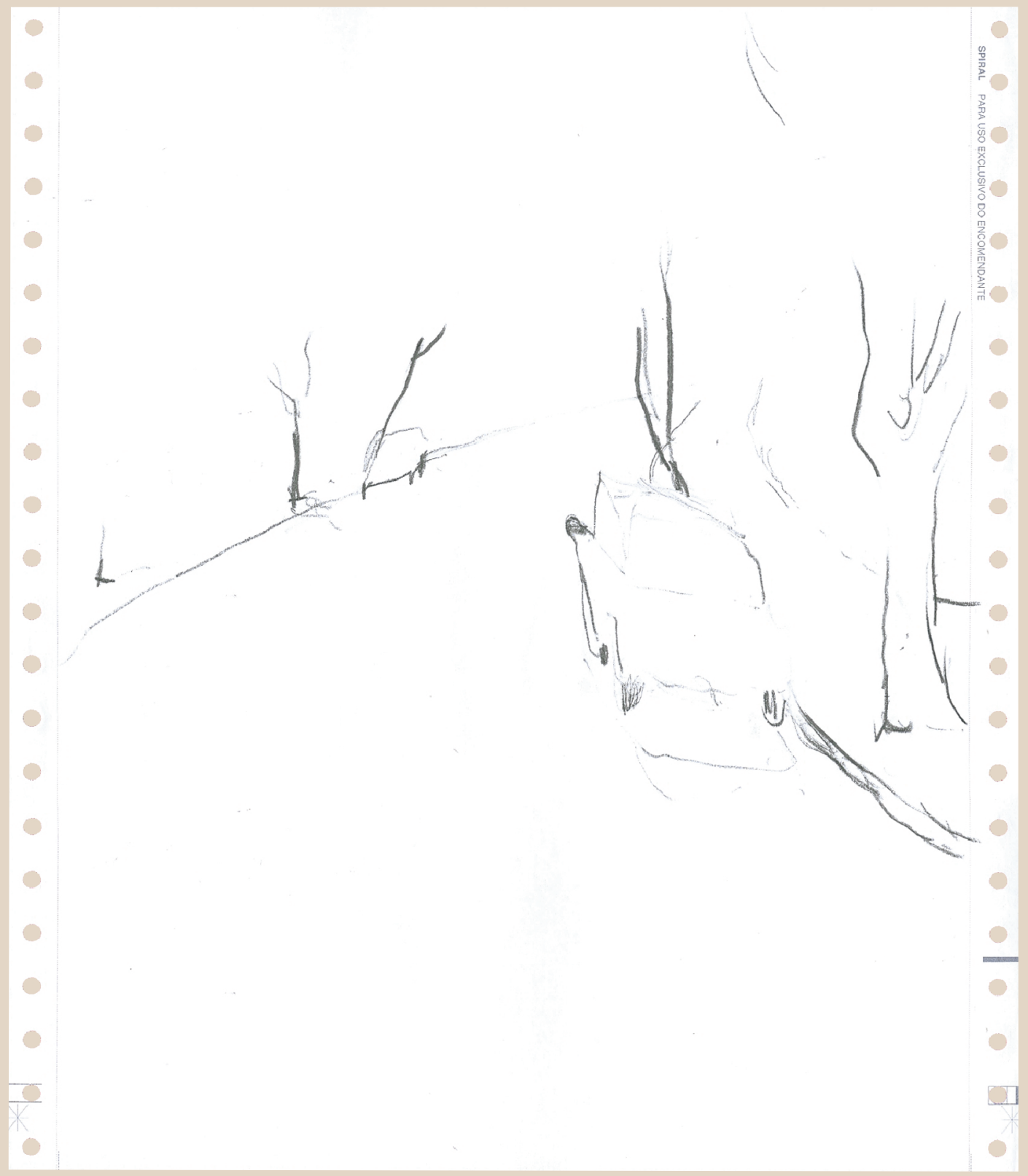


Gosto da sombra sob os carros como abrigo. 


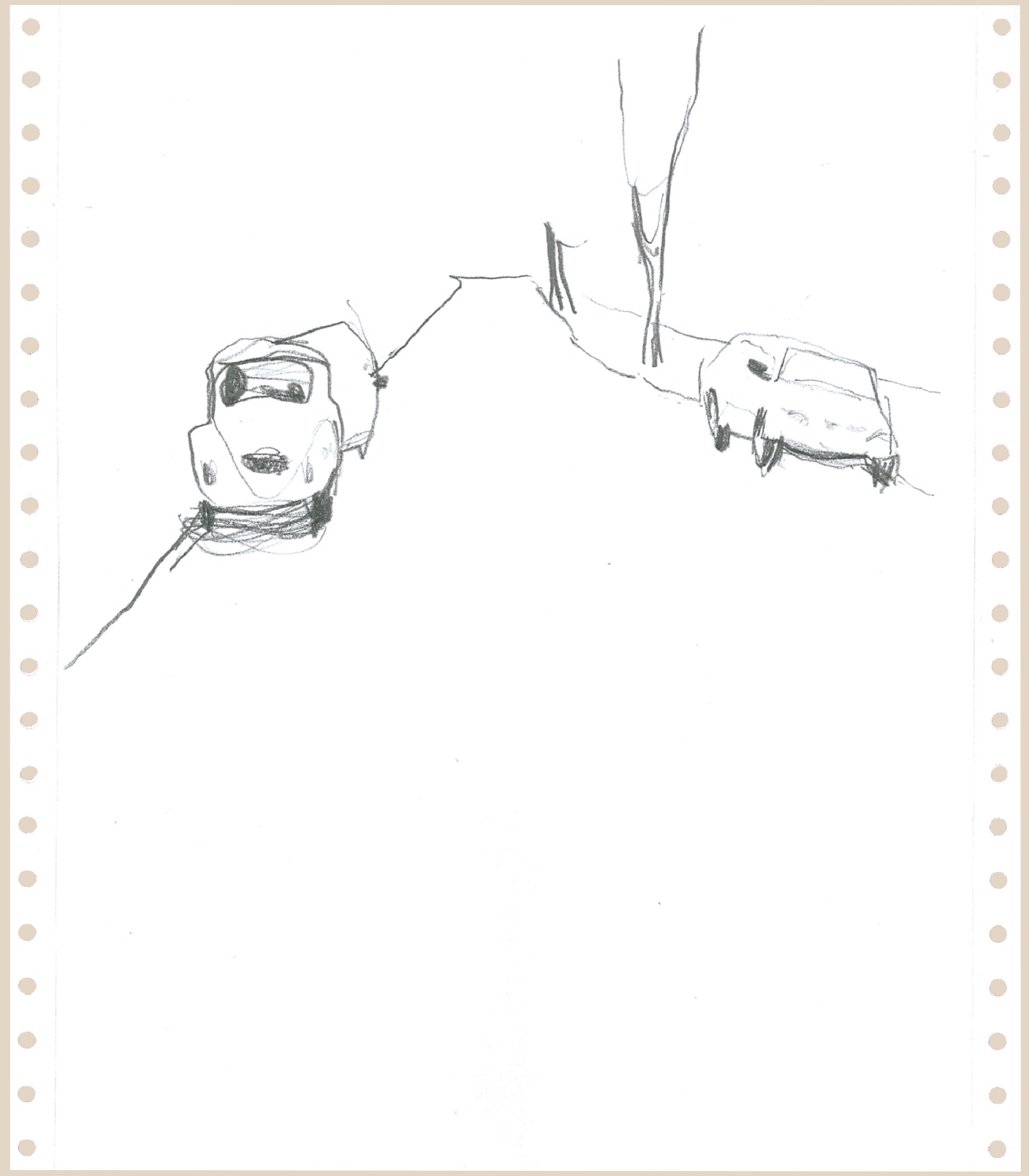




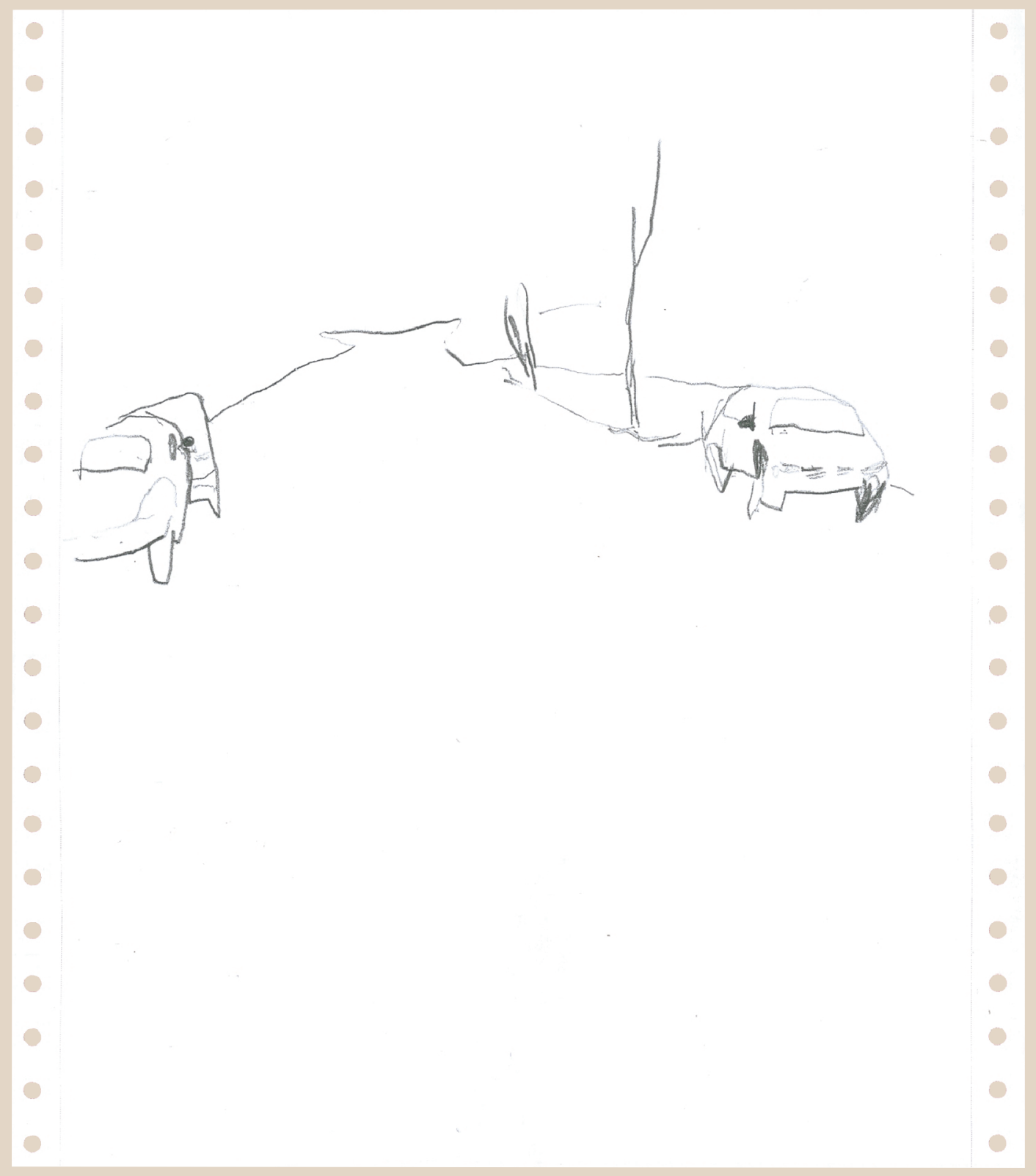




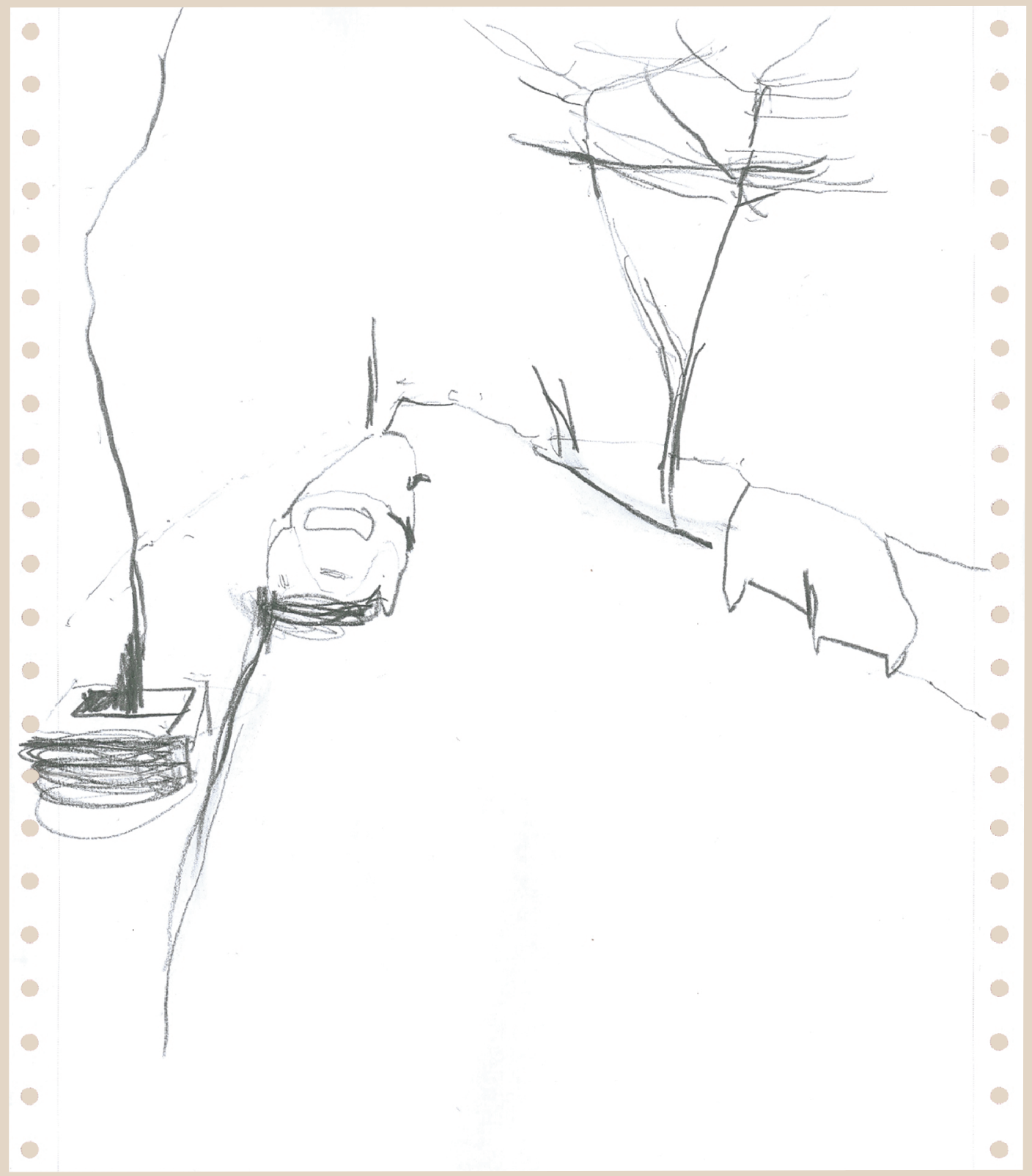




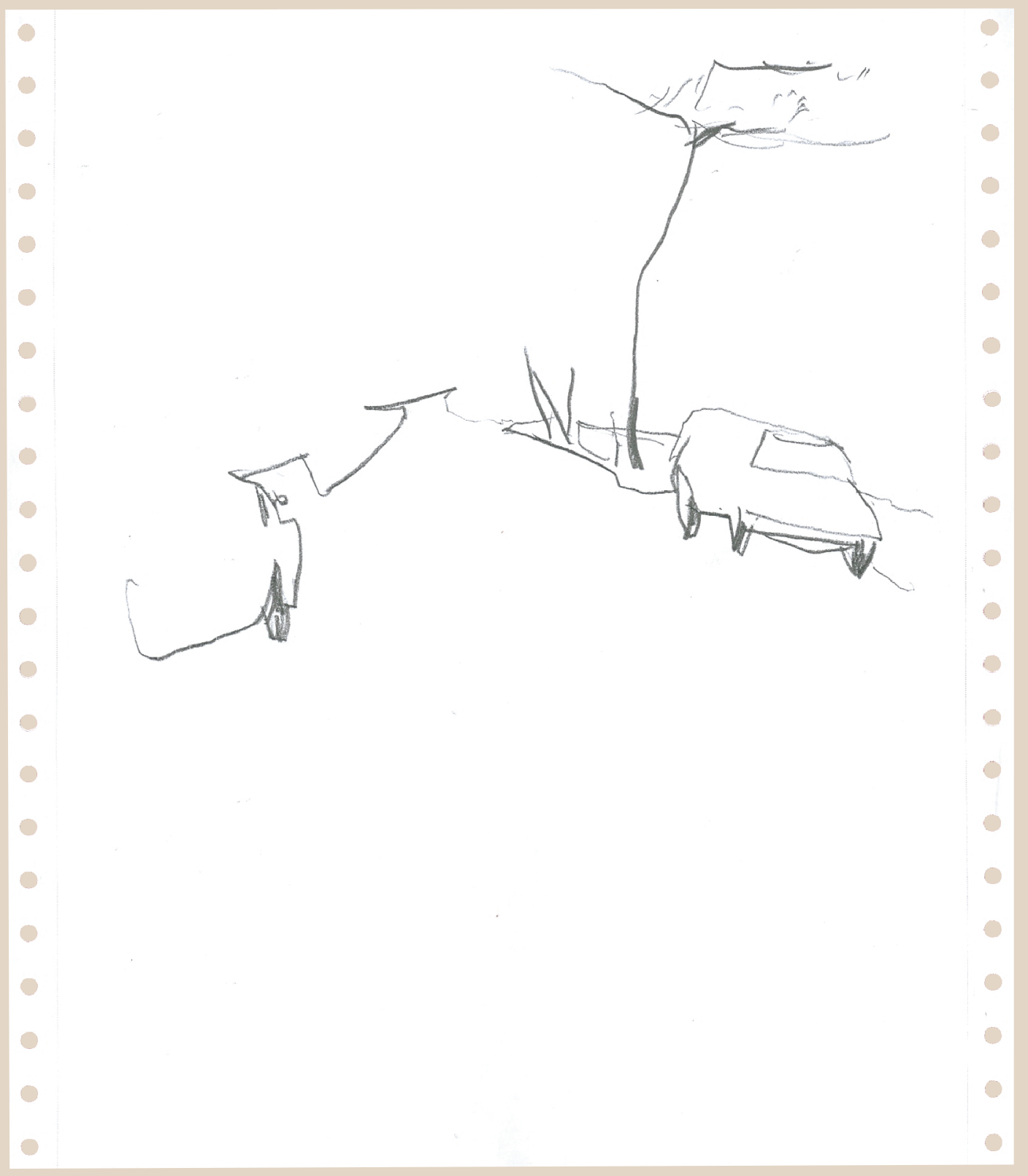




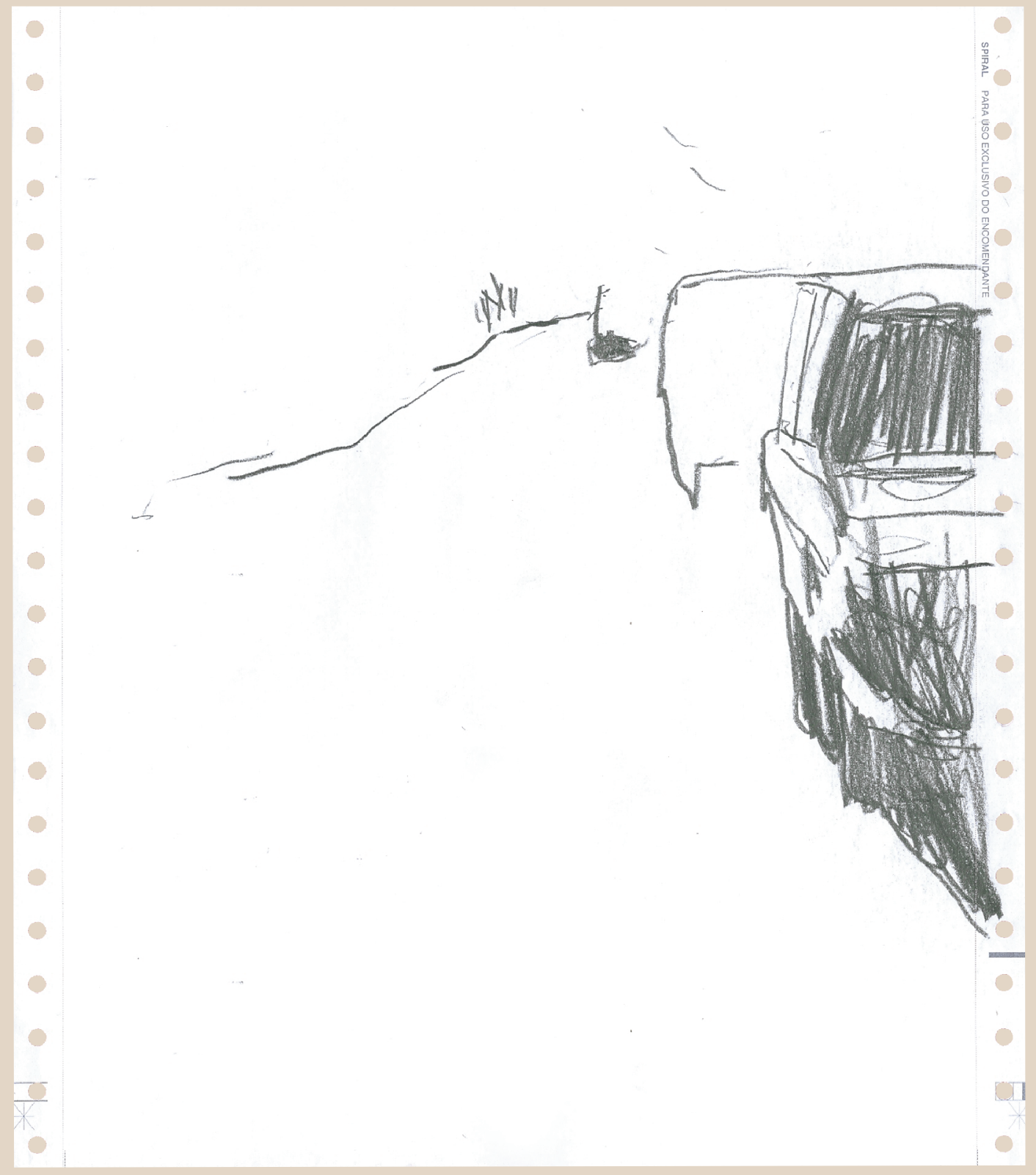




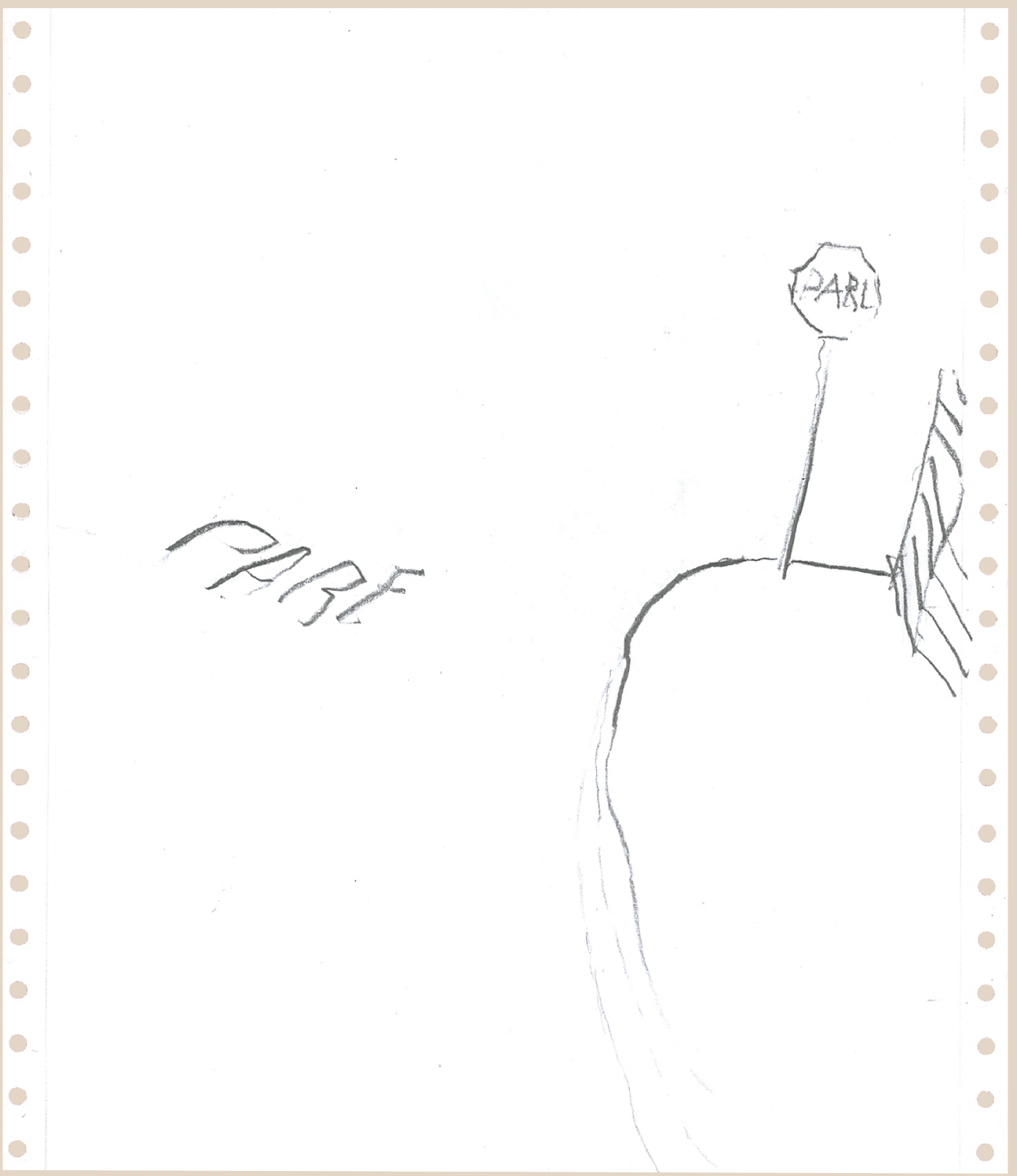



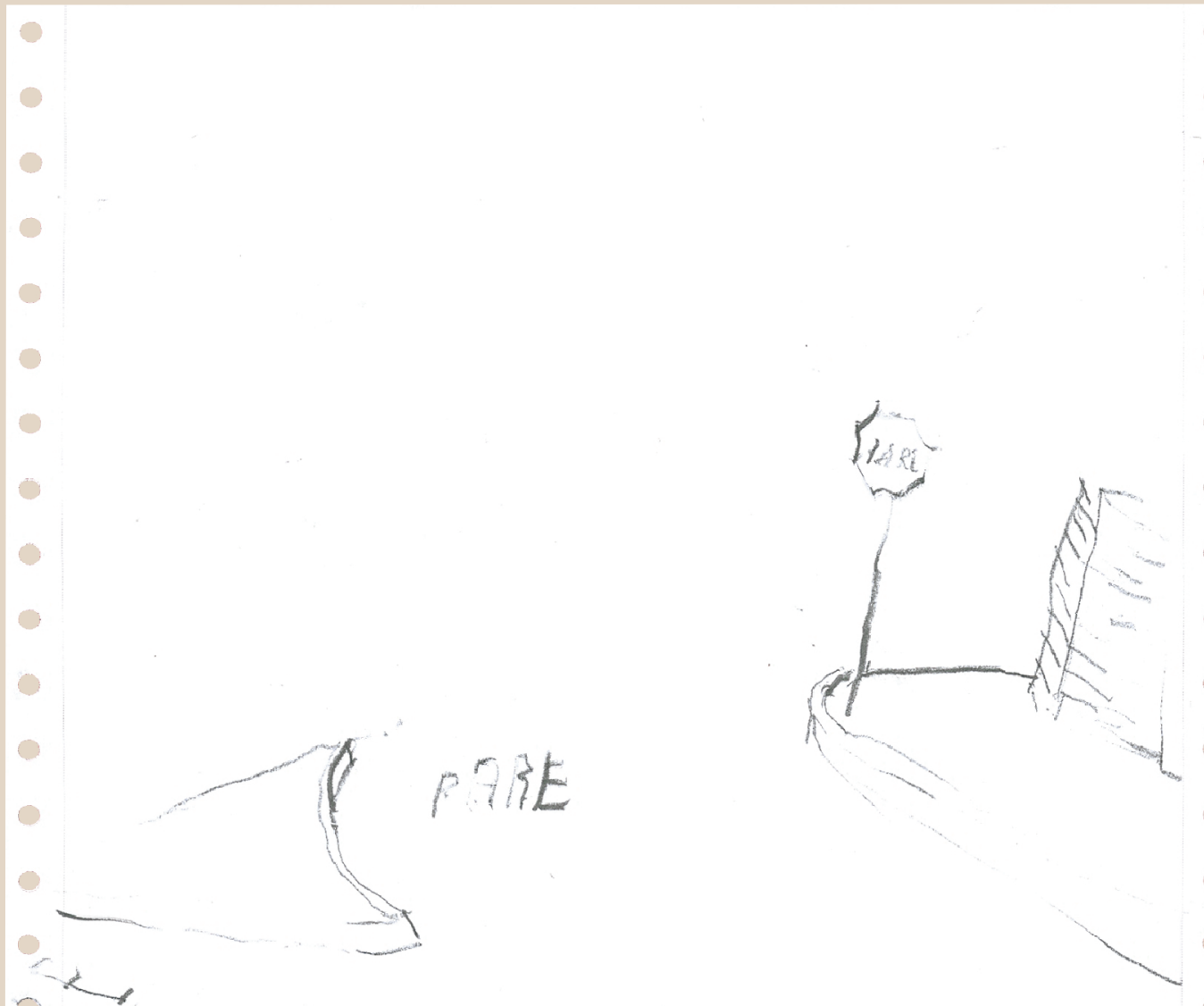


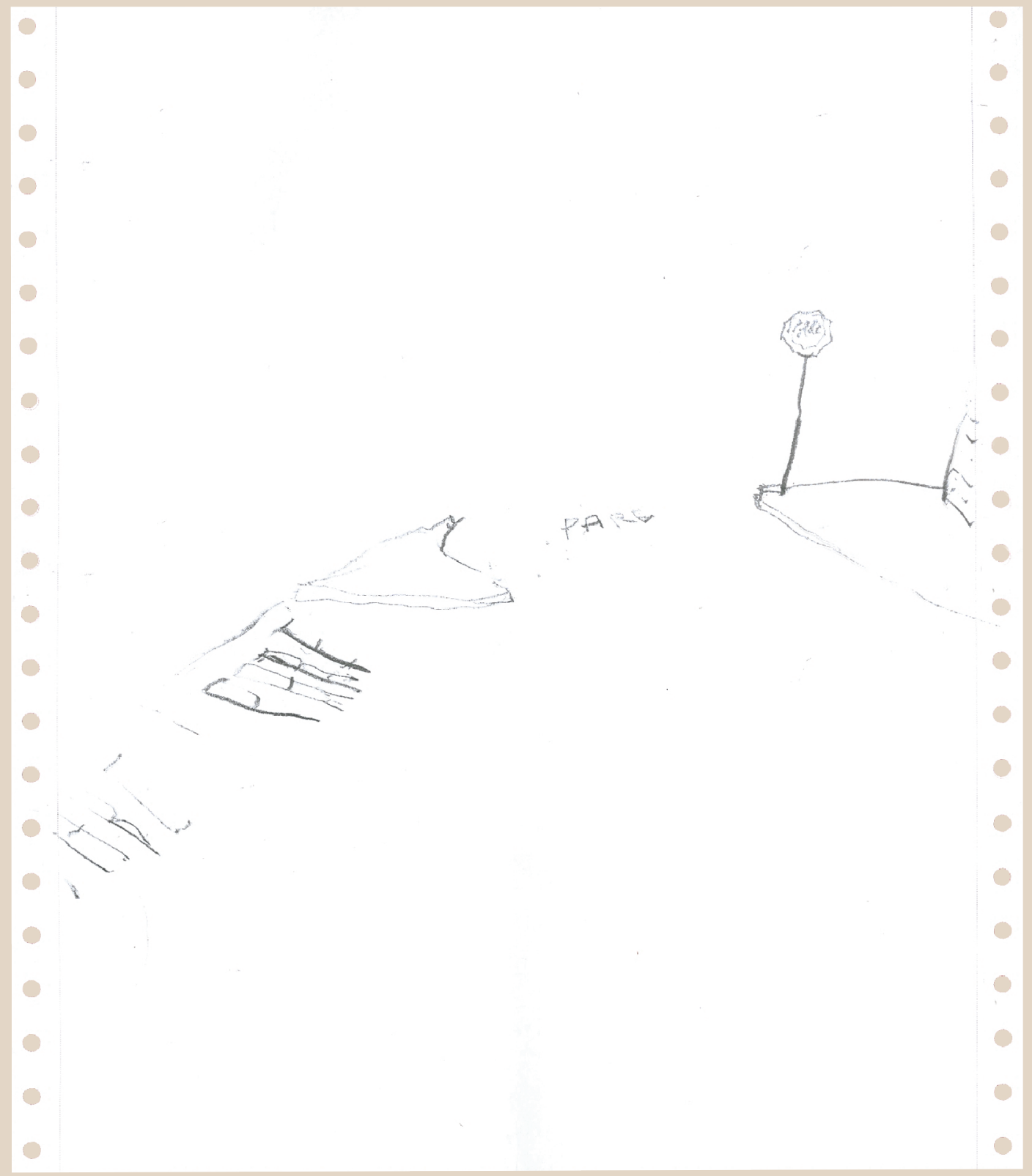




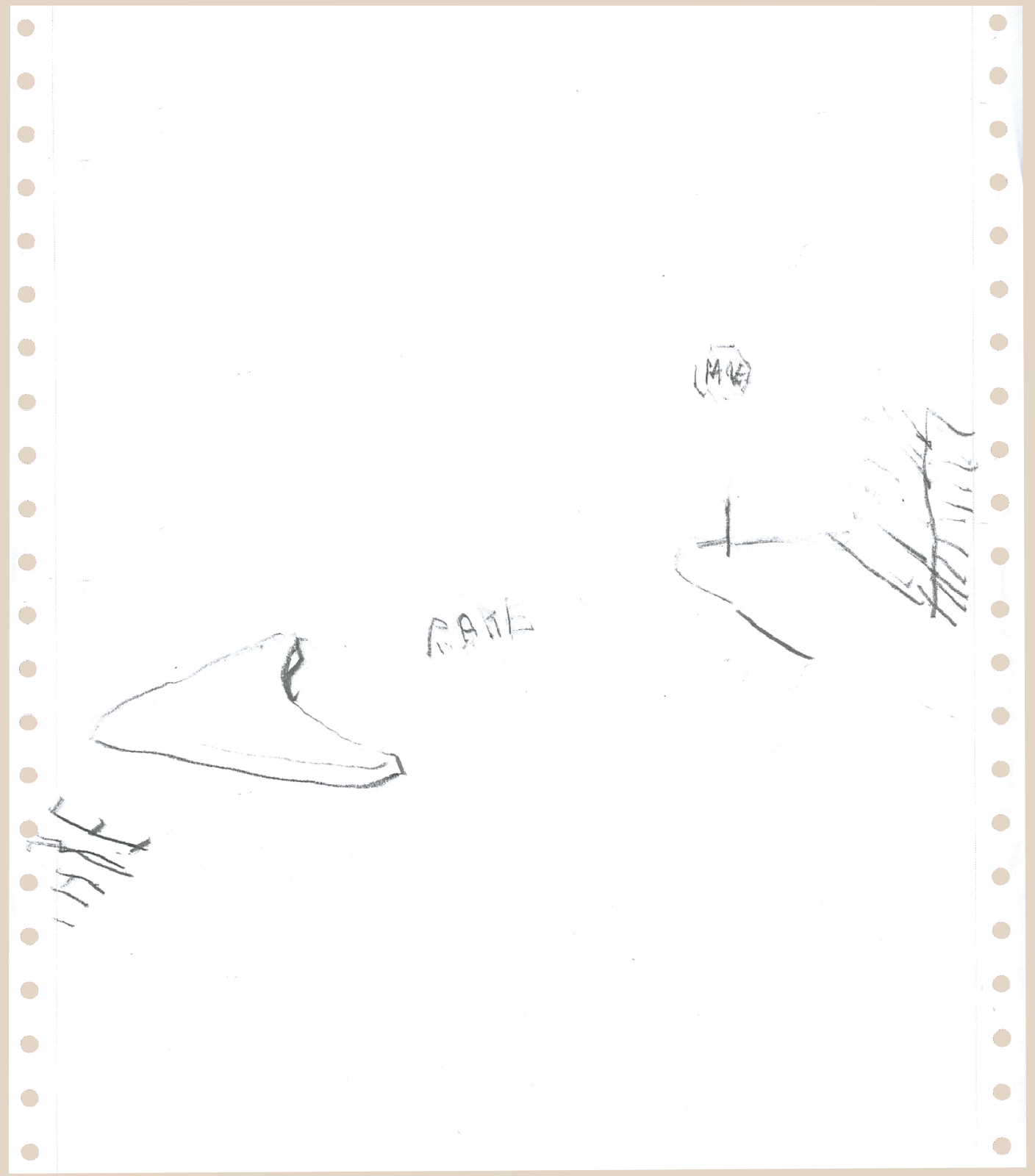


Os objetos são parte da superfície do espaço e alteram a sua percepção, um carro velho no meio da rua qualifica o cenário. 


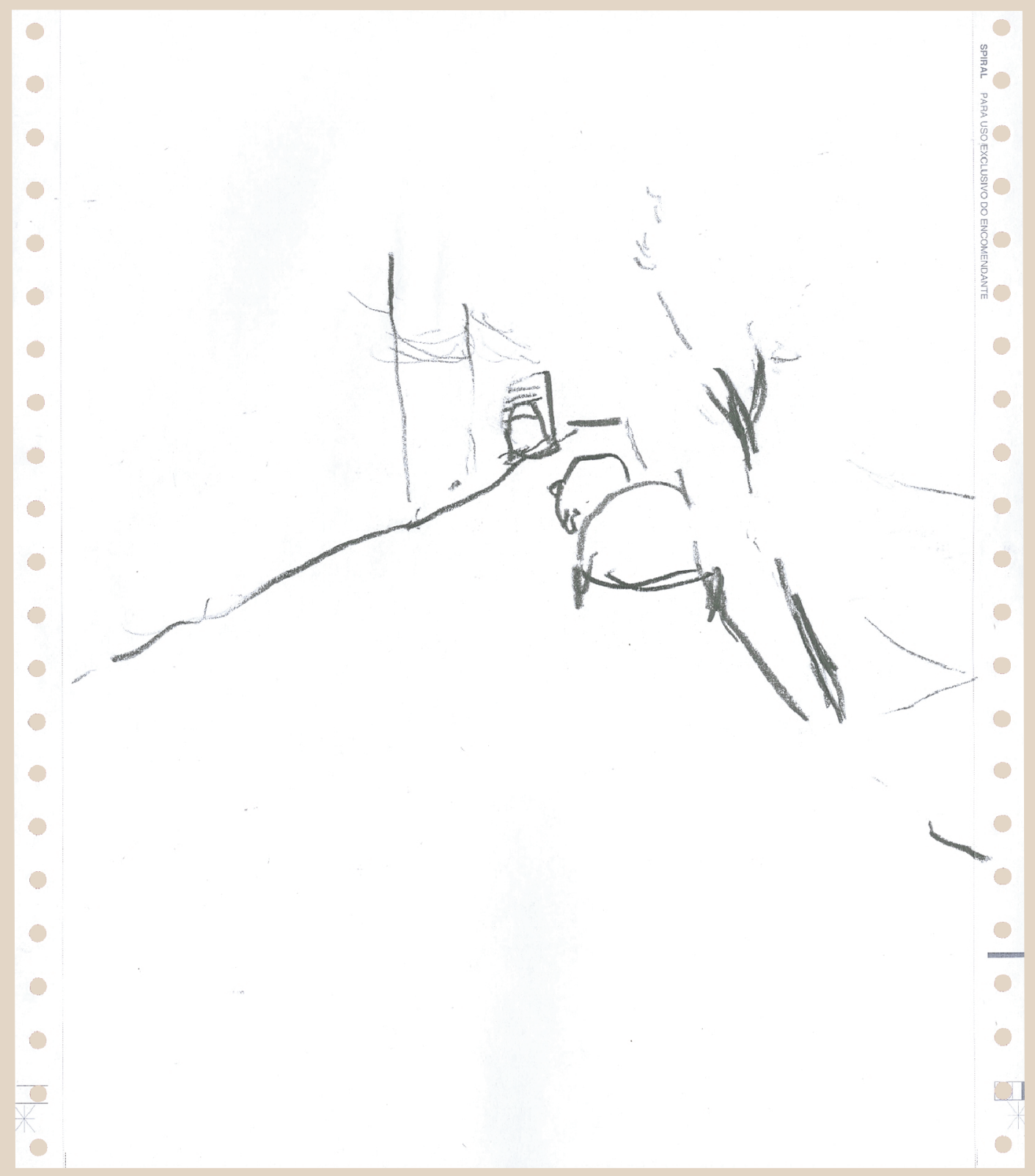




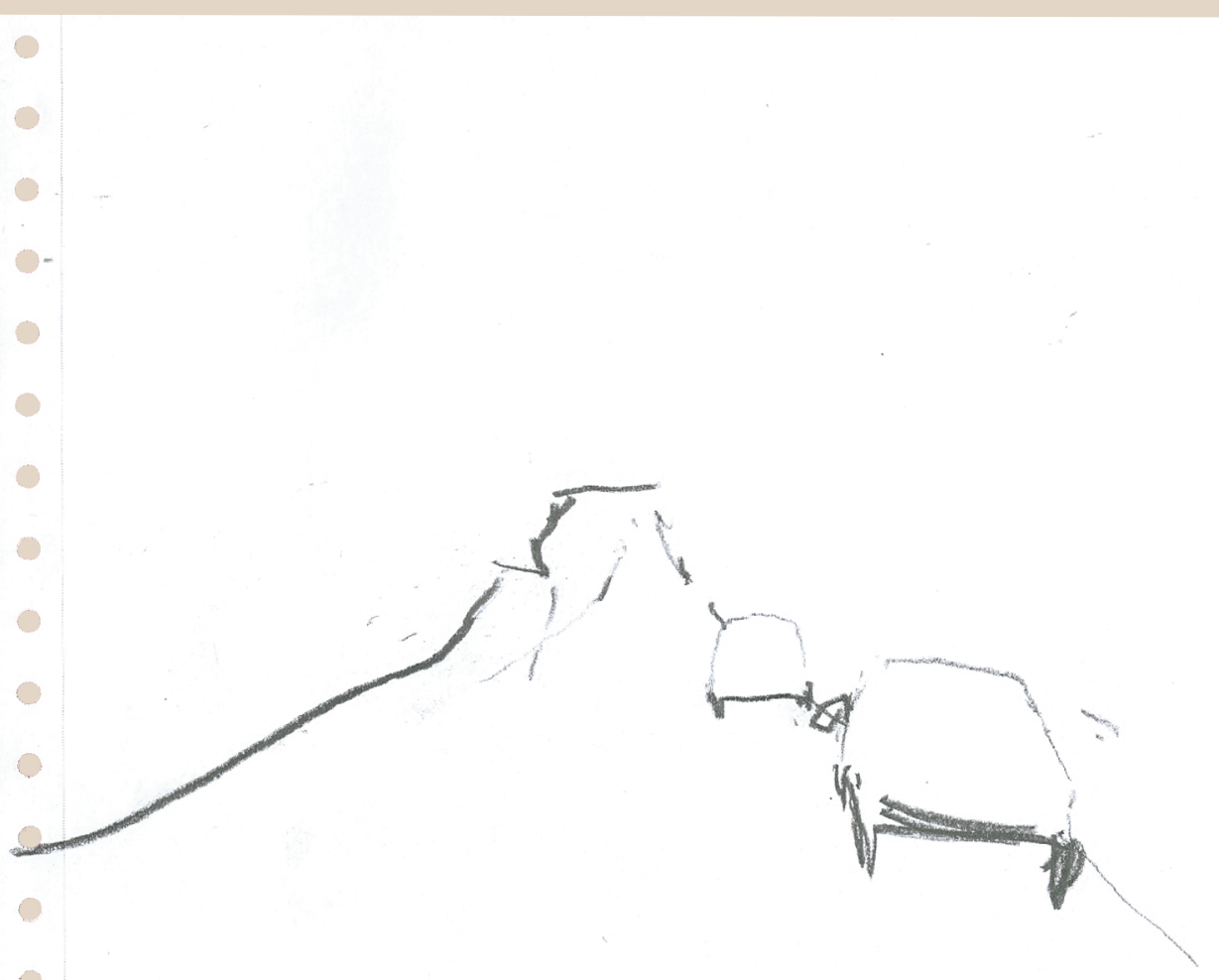




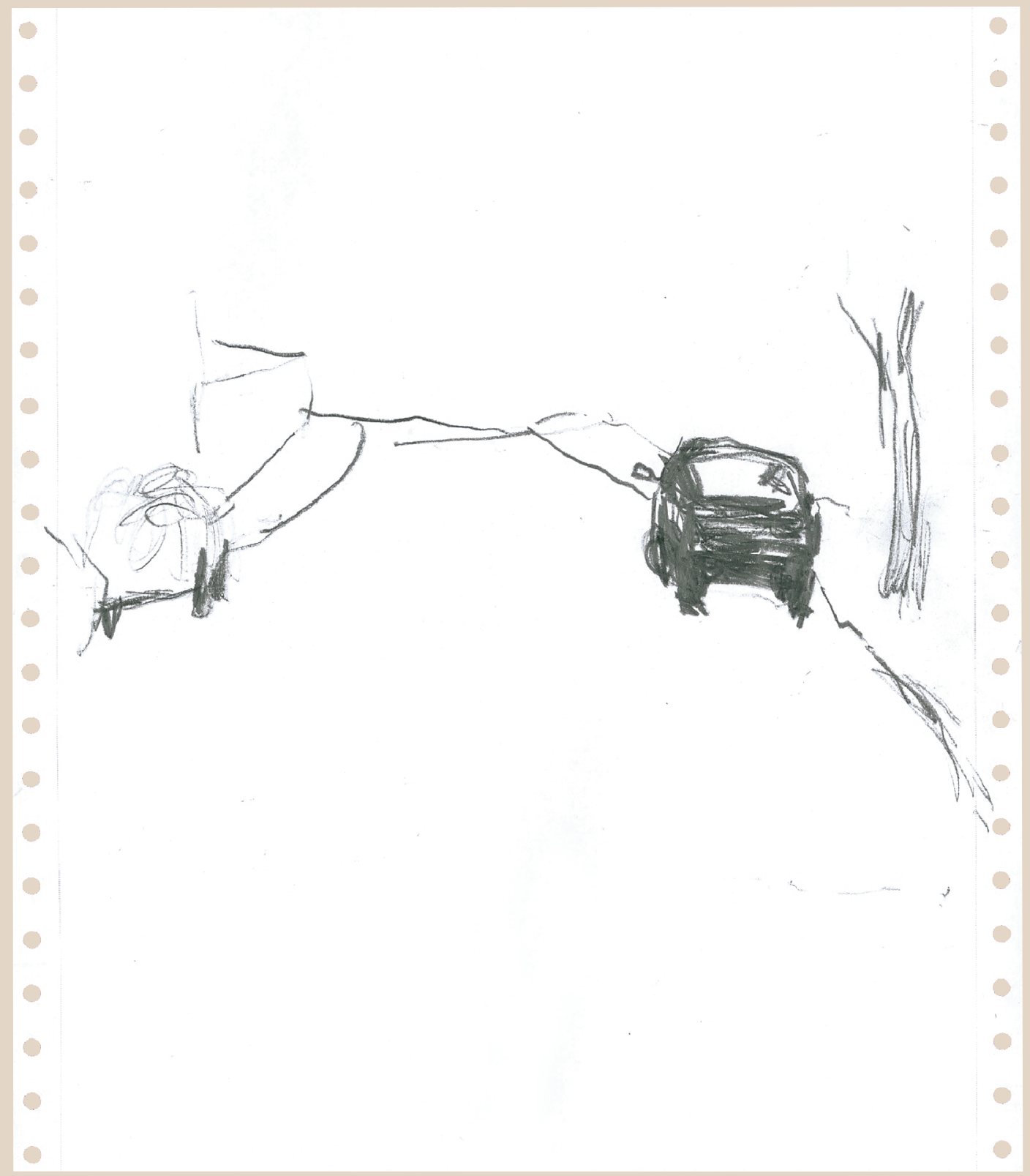


Os resíduos de espaço que consigo registrar nos desenhos desviam os limites do meu fluxo habitual de ações e pensamentos para caminhos alternativos entre as superfícies do que é visivel. 
10.5

Ruas vazias e carros velhos evidenciam uma possibilidade de perda, uma forma para o tempo passando. 
<smiles>C=CCCC</smiles> 
<smiles>C=C1CCCCC1</smiles> 
A perspectiva, revista e acentuada pela variação de intensidade das linhas, orienta um encaixe precário. 


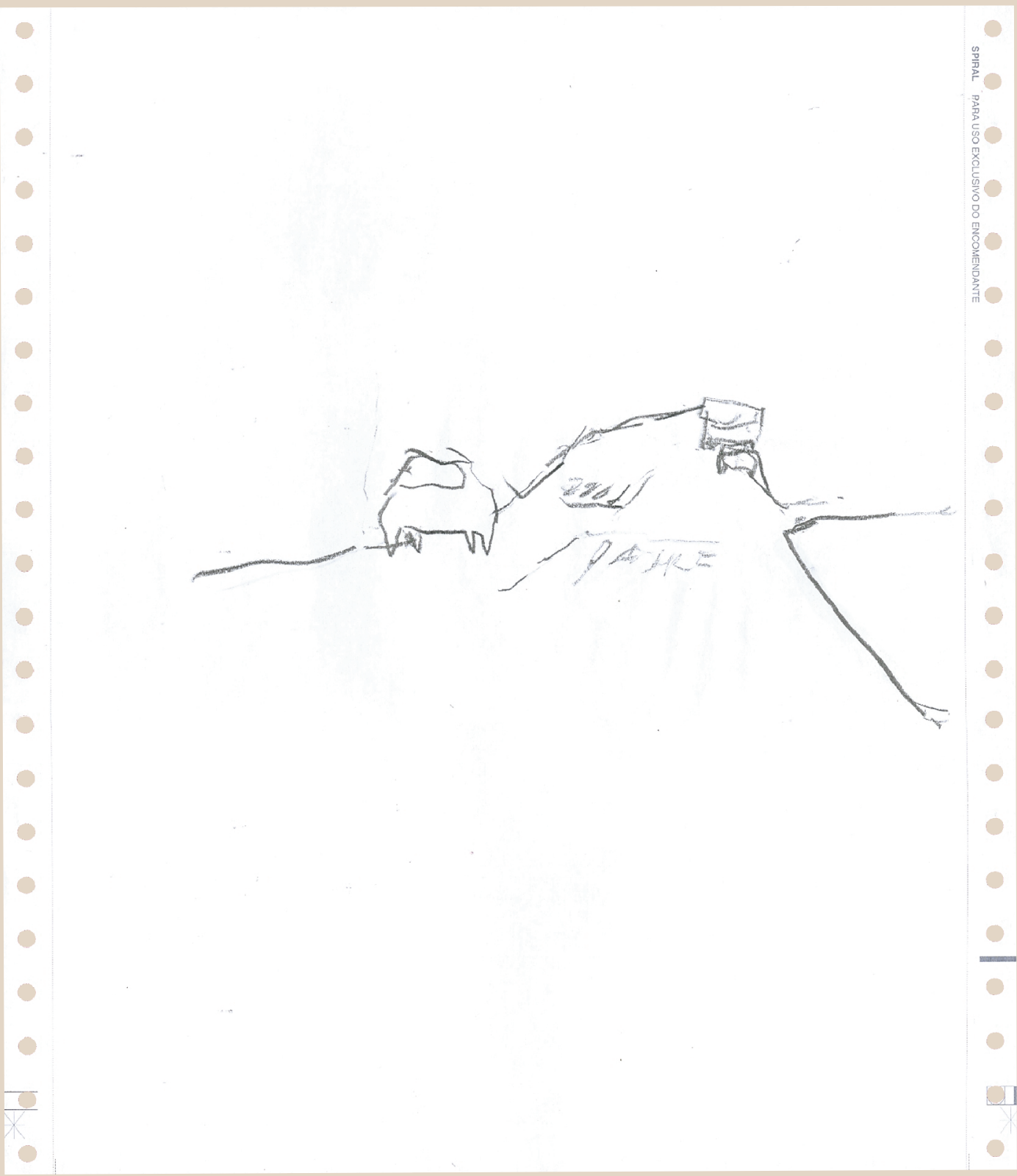

